
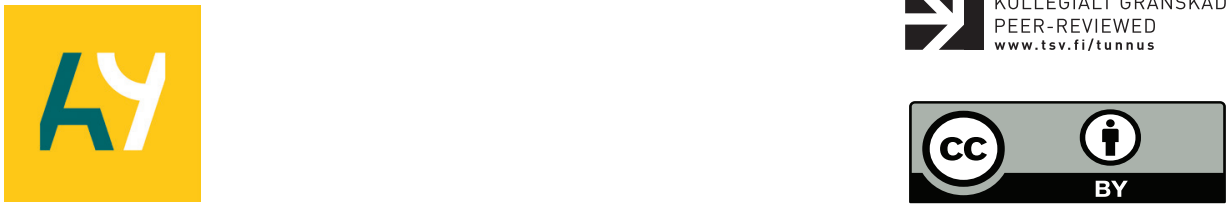

Maija Halonen ${ }^{\mathrm{a}}$

\title{
Jålkiteolliset luontoarvot ja materialismit metsätalouden muokkaamassa maisemassa
}

\begin{abstract}
Postindustrial values and materialisms of nature in forestry-dominated landscape Industrial use of nature and the end products seem to reflect the archetype of materialistic human-nature relationship whereas postindustrial materialisms tend to remain undefined or will be lump together as postmaterial. The aim of this article is to enrich the conception of materialistic premises and instrumental values regarding the postindustrial use of forests. This case study focuses on the eastern side of Lieksa, Finland, which is characterised by a multifunctional forested landscape. The narrative interviews with residents form the basis of the data to which the interpretative analysis of materialisms is then applied. Based on the results, postindustrial forest use tends to be linked to different kinds of materialistic forms, sometimes also through industrial forest use. The end value may be immaterial experience but to reach this experience materialistic commodities may be needed or nature itself will be changed in materialistic ways. The postindustrial human-nature relationship can be typified into four materialists categories: commodity basis defined by the end value, cultivation of nature into instrumental infrastructure, consuming nature as instrumental infrastructure, and indirect commodities instrumentally enabling human-nature relation.
\end{abstract}

Keywords: postindustrial materialism, multifunctional forest landscape, valuing of natural resources, human-oriented nature-relationship, narrative interview

\section{Johdanto}

Luonnonvarat ja niihin liitetyt arvot käsitetään harvemmin täysin yhteneväisesti (Oksanen 2000). Tässä artikkelissa luonnonvarat ymmärretään aiempaa tutkimuskirjallisuutta mukaillen luonnoksi, jota ihminen hyödyntää eri tavoin kuten teollisesti raaka-aineena, jälkiteollisesti elämysten lähteenä tai tulevat sukupolvet huomioivan suojelun kohteena (Mather 1990; Eisto 2009; Rannikko \& Määttä 2010). Pelkästään metsävaroihin on liitetty pitkä lista erilaisia käyttötapoja luontaistaloudesta esteettisiin arvoihin (Kangas \& Kokko 2001). Näkökulmani artikkelissa on ihmiskeskeinen, jonka mukaisesti tulkitsen luontoarvon määrittymistä erilaisen hyödyntämiskeinojen, konkreettisten käyttötapojen sekä niiden hyväksyttävyyden perusteella. Luontoarvot puolestaan kuvastavat tapaani

${ }^{a}$ Historia- ja maantieteiden laitos, Itä-Suomen yliopisto, maija.halonen@uef.fi 
hahmottaa monimuotoisia luontosuhteita, jotka ilmentävät erilaisia käsityksiä luonnon ihmisille tarjoamista mahdollisuuksista (vrt. Haila \& Lähde 2003, 16-23). Soinia ym. (2008, 10) mukaillen luonnonvarojen arvottaminen viittaa toimintaan, jonka avulla luontoarvoja määritetään. Arvottavaksi toiminnaksi tulkitsen sekä arvoista käytävän keskustelun että konkreettisen toiminnan, joiden myötä ihminen muokkaa tai käyttää tietynlaisten luonnonvarojen muodostaman maiseman luontomateriaaleja. Lähtökohtaisena kiinnostuksenani on eritellä luontomateriaaleihin kohdistuvia konkreettisia hyödyntämiskeinoja ja tehdä erittelyn pohjalta aiempaa tutkimuskirjallisuutta täydentäviä tulkintoja ihmislähtöisen luontosuhteen erityyppisistä materialistisuuksista.

Luonnonvaroihin liittyvän keskustelun katsotaan voimistuneen erityisesti 2010-luvulle tultaessa, jolloin kiinnostus luonnonvarojen intensiivistä käyttöä kohtaan kasvoi jälkiteollisen metsänkäytön lisäämiseen keskittyneen ajanjakson jälkeen (esim. Rannikko \& Määttä 2010, 7-8). Kansallisestikin merkittävät luonnonvara-alueet sijoittuvat tyypillisesti päätöksenteon ja väestökeskittymien näkökulmasta kauas syrjäseuduille (vrt. Knuuttila \& Rannikko 2009, 49-50), joiden taloudellisen kehityksen alkusysäys on usein ollut luonnonvarojen teollisessa käytössä (Kotilainen ym. 2015; Halonen 2019). Luonnonvarojen hyödyntämiseen liittyvien arvojen tarkastelu on pitkälti keskittynyt paikallisen kokonaisuuden sijasta (vrt. Rannikko 2010, 261) yhden luonnonvara-alueen kuten tietyn metsän, suon tai malmiesiintymän eri tarkoitusten mukaiseen hyödyntämiseen (esim. Albrecht \& Åkerman 2016; Sairinen ym. 2017). Tyypillisimmissä tilanteissa teollistaloudelliset arvot törmäävät sosiokulttuuristen tai ekologisten näkökulmien kanssa (vrt. Roiko-Jokela 2003, 12-20; O’Neill ym. 2008, 4-5). Viimeisimpänä esimerkkinä toimii jako epäaidoksi tai vääränlaiseksi metsäksi esitetyn talousmetsän ja oikeaa metsää edustavan luonnontilaisen metsän välillä (vrt. Jokiranta ym. 2019, 9-11). Jännite teollisen ja jälkiteollisen arvottamisen välillä näkyy siten vahvana erilaisten luontosuhteiden kohtaamissa tilanteissa, kuten tämänkin tutkimuksen empiria paikoin osoittaa.

Talousnäkökulmaan nojaava luonnonvarojen käyttö näyttää erottautuvan omana kategorianaan myös luontosuhteen materialistisuutta määritettäessä. Intensiivisen teollisuuskäytön ja luontomateriaaleista valmistettujen hyödykkeiden on ensinnäkin katsottu ilmentävän tyypillistä esimerkkiä materialistisesta luontosuhteesta (ks. Haila 1990, 134-135). Metsän teollinen käyttö onkin aiemmassa tutkimuskirjallisuudessa rinnastettu eksplisiittisesti ainoaksi materialistiseksi käyttötavaksi, kun taas jälkiteolliset käyttötavat on lähtökohtaisesti liitetty jälkimaterialistisiin arvoihin (Mather 2001). Samankaltainen tyypittely näyttää vallitsevan tulevaisuuden hyvinvointisuuntauksien ennakoinneissa, joissa aineellisuutta edustava luonnonvaratalous on asetettu luonnon aineettoman kulutuksen ja elämänlaadun vastapuolelle (ks. Kuhmonen \& Kuhmonen 2015).

Näille määritelmille yhteistä on se, että luontosuhteen materialistisuus ja sille synonyymina ymmärtämäni aineellisuus määrittyvät ennen kaikkea luontomateriaalista valmistetun fyysisen lopputuotteen ja teollisuuteen nojaavan hyödyn perusteella. Tämän näkökulman ongelmana pidän sitä, että käytännössä jälkiteollista luontosuhdetta kuvaavat materialistisuudet jäävät määrittelemättä tai tulevat yksioikoisesti niputetuiksi jälkimaterialistisina materiaalittomiksi. Kuitenkin edellä esitetyissä kiistoissakin on lopulta kyse eri tarkoitusten mukaisesta luontomateriaalin käytöstä ja hyödynnettävyydestä. Näitä kiistoja käyvät luontoa omista näkökulmistaan arvottavat ihmiset ja luontomateria on se, josta kiistellään.

Tavoitteenani ei ole hylätä luonnon teollista käyttöä ja luonnosta valmistettuja hyödykkeitä materialistisen luontosuhteen arkkityyppeinä vaan rikastuttaa käsitystä jälkiteollisiksi määrittyvien käyttötapojen materialistisesta perustasta ja luonnon välineellisyydestä. Lähden materialistisen luontosuhteen perusteena pidetystä olettamuksesta, jonka mukaan luonto on välineellisesti olemassa ihmisen hyödyntämisen kohteena (ks. Haila 1990, 134-135), mutta en kytke sitä yksinomaan teollistaloudellista luonnonvarojen käyttöä tai lopputuotteita koskevaksi lähestymistavaksi. Teoreettisen viitekehyksen ja empiiristen 
havaintojen yhdistelmän avulla muodostan aiempaa jaottelua täydentävän ja samalla uudistavan jäsennyksen luontosuhteen materialismeista (vrt. Swedberg 2012), jotka esitän johtopäätöksissä jälkiteollisia materialismeja käsitteellistävinä kategorisointeina.

Tulkitsen tutkimuksen empiirisen alueen intensiivisen luonnonvarojen käytön dominoimaksi monitoiminnalliseksi maisemaksi (multifuctional landscape), jota myös alueen asukkaat voivat arkielämässään eri tavoin hyödyntää (vrt. Brandt \& Vejre 2004, 9). En määrittele maisemaa ainoastaan pinnanmuotojen kuvailuna, visuaalisena näkymänä ja siihen liitettynä estetiikkana vaan kulttuurimaantieteelle ominaisella tavalla näen maiseman myös ihmisen toiminnan ja kokemuksen sekä niiden materialistisuuden määrittämisen olennaisena osana (Schein 2010; Pitkänen 2011). Aiempien tutkimushavaintojen (ks. Valkonen 2008, 263) perusteella otaksun paikallisten asukkaiden lähiluontoon liittyvien kokemusten kuvastavan erilaisia käyttötapoja ja siten mahdollistavan monimuotoisten materialismien erittelyn. Oletan, että intensiivisen metsätalouden ja jälkiteollisten hyödyntämiskeinojen sulautuminen monitoiminnalliseksi metsämaisemaksi merkitsee myös erilaisten materialististen muotojen risteämistä.

Vaikka tarkastelenkin luontosuhteen materialistisuutta yksilöiden arkikokemusten välittämänä, tulkitsen näiden kokemusten olevan kytköksissä paikallista kehityskulkua muovanneisiin käyttötapoihin ja luontoarvoihin (ks. Rannikko 2010, 261). Tarkastelen luontoarvoja ja materialismeja täten ensisijaisesti tietyn ajan, paikan ja kokijoiden leimaamina, joiden kautta kuitenkin välittyy kertomuksia myös luonnonvarojen käyttöön liittyvästä yhteiskunnallisesta muutoksesta (vrt. Manfredo 2009; Lähde 2012, 97).

Tulkitsen luonnon arkista käyttöä ja luontosuhdetta kuvaavien kertomushaastattelujen pohjalta, millaisia jälkiteollisia materialismeja monitoiminnallisen metsämaiseman hyödyntämiseen liittyy. Lähestyn tätä tutkimuksen pääkysymystä kahden täsmentävän alakysymyksen avulla: Miten jälkiteolliset luonnon käyttötavat, luontoarvot ja materialismit risteävät metsätalouden muokkaamassa maisemassa? Millaisia ristiriitoja käyttötapojen, luontoarvojen ja edelleen materialismien monimuotoisuuteen liittyy ja miten niitä ratkotaan?

\section{Teolliset ja jälkiteolliset arvot monitoiminnallisessa maisemassa}

Tutkimuksen teoreettinen viitekehys pohjautuu teollisen ja jälkiteollisen luonnonvarojen käytön sekä (moni)toiminnallisuutta korostavan maiseman käsitteisiin. Nämä käsitteet ovat toisiinsa limittyviä, vaikkakin kumpuavat osin myös toisistaan irrallisista keskusteluista. Viitekehyksille yhteistä on, että keskustelut ovat pitkälti angloamerikkalaisten tutkijoiden viitoittamia (esim. Mather 1990; Wilson 2001; McCarthy 2005; Milbourne ym. 2008; Schein 2010; Kramkowski \& Mulvihill 2017), mutta myös suomalaisten tutkijoiden suoraan tai tematiikaltaan tutkimuksissaan hyödyntämiä ja suomalaisessa kontekstissa tulkitsemia (esim. Björn 2000; Tanskanen 2000; Soini ym. 2008; Pitkänen 2011; Rannikko \& Salmi 2018). Molemmille keskusteluille yhteistä on ihmisen ja luonnon välisen suhteen määrittely ja toimintakeskeisyys näiden määritelmien muodostumisessa. Materialistisuutta sivutaan käsitteiden yhteydessä, mutta materialismin seikkaperäisempi tarkastelu näyttää jääneen sivurooliin. Tulkitsen tämän aukoksi, jota artikkelini avulla täydennän.

Matheria (2001), McCarthya (2005) sekä Rannikkoa ja Salmea (2018) tulkiten ymmärrän teollisen luonnonvarojen käytön viittaavaan teollisuuden tarpeista lähtevään korkean intensiteetin hyödyntämiseen, minkä myötä luonnonvaroja kuten metsiä kasvatetaan, kaadetaan ja prosessoidaan lopputuotteiksi. Jälkiteollisen luonnonvarojen käytön määrittely on tätä monipolvisempaa ja riippuvaisempaa kunkin määrittelijän tekemistä painotuksista. Matherin (2001, 263) määritelmässä jälkiteolliset käyttötavat yhdistyvät erityisesti luonnonvaroja hyödyntäviin palveluihin, jotka laajemmin liittyvät ihmisten virkistykseen ja vapaa-aikaan (Rannikko \& Salmi 2018, 629). McCarthyn (2005, 774) tulkinnassa jälkiteollinen yhdistetään sellaisiin ominaisuuksiin kuten luontomaiseman mukavuus 
ja esteettisyys, jotka tulkitsen edelleen palvelujen käyttöä, virkistäytymistä ja vapaa-aikaa tukeviksi arvoiksi. Tästä esimerkkinä voidaan käyttää Hiltusen ym. $(2014,69)$ havaintoa mukavuusmaisemiin hakeutuvasta vapaa-ajan asumisesta, joka kohdistuu erityisesti luonnonoloiltaan houkutteleville ja visuaalisesti vetovoimaisiin maaseutumaisemiin. Hieman erilaisten, joskin toisiinsa linkittyvien käyttömuotojen lisäksi jälkiteollisina arvoina mainitaan luonnon- tai sille rinnasteisena ympäristönsuojelu (Mather 2001; Rannikko \& Salmi 2018).

Jälkiteollisuutta korvaavaksi termiksi on toisinaan ehdotettu monitoiminnallista maisemaa (Wilson 2001; McCarthy 2005). Tässä artikkelissa monitoiminnallisuutta ei voida kuitenkaan rajata jälkiteolliseksi, vaikkakin erityyppiset jälkiteolliset toiminnot voivat jo yksistään muodostaa monitoiminnallisen maiseman. Empiirinen tutkimusalueeni on ensinnäkin edelleen metsätalouden dominoima, mikä vaikuttaa siihen, miltä maisema näyttää sekä siihen, miten metsää voi hyödyntää. Lisäksi, kuten Mather ym. (2006, 443) ovat esittäneet, teollisen ja jälkiteollisen erottaminen toisistaan on tarpeen kuvastamaan niiden toisistaan poikkeavia hierarkioita ja painotuksia, vaikkakin ne yhdessä muodostaisivat monitoiminnallisen maiseman. Yhteiskunnan tasolla tämä tarkoittaa erityisesti sitä, että talousperustainen metsämaisema nähdään sekä teollisin että jälkiteollisin käyttöperustein arvotettuina ja nämä erityyppiset arvot huomioidaan suunnitteluvaiheessa monikäyttöisyyden mahdollistavalla tavalla (vrt. Kramkowski \& Mulvihill 2017). Monikäyttöisyyden tavoittelu suunnitteluvaiheessa voi tarkoittaa talousmetsäksi tarkoitetun metsäalueen muokkaamista siten, että se mahdollistaa myös muut metsänkäyttömuodot kuten virkistäytymisen (Eyvindson $y m$. 2021). Tämän lisäksi monikäyttöisyys yhteiskunnan tasolla on liitetty myös talousmetsäksi perustetun alueen pilkkomiseen eri käytön mukaisiin alueisiin kuten empiirisen tutkimusalueen keskiössä sijaitsevan Ruunaan ympäristössä on tapahtunut (Eisto 2009, 141-142).

Yksilöiden kohdalla muutos teollisesta metsänkäytön painotuksesta jälkiteolliseen on tarkoittanut ennen kaikkea sitä, että sama luontoympäristö metsineen ei ole enää yhtä merkittävässä roolissa metsätaloustöiden tarjoajana lähialueen asukkaille kuin se on ollut aikanaan muun muassa lukuisille asutustilallisille ja metsureille (ks. Rannikko 2008; Kietäväinen 2011). Näin on käynyt myös tämän tutkimuksen empiirisellä tutkimusalueella, minkä vuoksi luontosuhteen muutos kuvastaa yhä useampien asukkaiden elinkeinojen irtaantumista teollisesta luonnonvarojen käytöstä. Muutos sinänsä ei ole merkinnyt irtaantumista metsäteollisuuden tarjoamista hyödykkeistä, mutta yksilöiden toiminta metsämaisemassa on kytkeytynyt ennemmin jälkiteollisiin hyödyntämiskeinoihin kuin teollisuutta hyödyntävään työhön.

Jakoa teolliseen ja jälkiteolliseen ei näin ollen hylätä vaan nivotaan yhteen monitoiminnallisen maiseman kanssa, minkä on todettu soveltuvan erityisesti paikallisten kohteiden tarkasteluun (Almstedt ym. 2014). Brittiläistä metsänkäyttöä tutkineiden Milbourne ym. $(2008,616)$ mukaan teollisen ja jälkiteollisen metsänkäytön yhdistäminen on usein käytännössä ongelmallista, koska teollisuuden tarpeisiin muokatut talousmetsät voivat muodostua vaikeakulkuisiksi ja visuaalisesti houkuttelemattomiksi. On kuitenkin huomioitava, että Suomessa metsätalouden tarpeisiin tehdyt metsäautotiet ovat osoittautuneet myös merkittäviksi metsien virkistyskäytön mahdollistaviksi kulkuväyliksi (Kosenius ym. 2013, 23-24, 45-46). Sepänmaan (2006, 242-243) mukaan peltoviljelyiksi kuvattuja tuotantometsiä ei puolestaan pitäisi hoitaa muista arvoista irrallisina, vaan hyvin hoidetussa tuotantometsässä taloudelliset arvot on sovitettu yhteen muiden arvojen kanssa. Valkosta (2008, 260-263) mukaillen teollisesta metsätaloustoiminnasta johtuvien hakkuiden voi katsoa muuttavan jälkiteollisten metsänkäyttäjien reittejä ja rajoittavan esimerkiksi marjastusta ja metsästystä tietyissä paikoissa, mutta metsätalouden ei nähdä välttämättä poissulkevan metsän muita käyttömuotoja. Nämä eri käyttömuotojen kohtaamiset ja niistä kumpuavat arkiset konfliktit tulkitsen tutkimusalueeni mielenkiintoisiksi erityispiirteiksi, joihin artikkelissani pureudun. 


\section{Kohti jälkiteollisia materialismeja}

Aiemmassa tutkimuskirjallisuudessa luonnonvaroihin liittyvät materialismitulkinnat rinnastuvat eksplisiittisimmin jakoon materialistinen/teollinen versus jälkimaterialistinen/ jälkiteollinen (Mather 2001; Curting \& Kragh 2014). Tämä jako perustuu luonnosta saatavaan lopulliseen hyötyyn, joka teollismaterialistisesti on tarkoittanut luontomateriaalista valmistettua hyödykettä, kun taas jälkiteollismaterialistisena materiaalitonta hyötyä kuten virkistäytymistä.

Mather ym. (2006) kuten myös myöhemmin Fletcher (2009) pohjaavat luonnonvaroihin liittyvän jälkimaterialistisen käsityksensä yleisemminkin hyvinvoinnin materialistisuutta ja jälkimaterialistisuutta käsittelevään muutokseen. Tämä näkökulma lähtee liikkeelle olettamuksesta, jonka mukaan materialistiset arvot kuten hyvä talous ja fyysinen turvallisuus ovat korvautuneet lisääntyvästi subjektiiviseen hyvinvointiin ja elämänlaatuun liitettävillä materiaalittomilla arvoilla (Inglehart \& Baker 2000). Näistä karikatyyriesimerkkeinä näyttäytyvät Fletcherin (2009) jälkimaterialistiset ekoturistit, jotka ovat valmiita tinkimään fyysisistä mukavuuksista saavuttaakseen nautinnollisia kokemuksia. Curtinin ja Kraghin (2014) prosessikuvauksessa nämä urbanisoitumisen myötä luonnosta irtaantuneet ja vieraantuneet ihmiset pyrkivät löytämään yhteyden takaisin luontoon jälkimaterialistisia luontoarvoja etsien. Suomalaisessa viitekehyksessä hyvinvointia tukeva muutos on tarkoittanut ennen kaikkea sitä, että ruokaa, puuta ja muita raaka-aineita tuottaneet metsämaisemat ovat muuntuneet yksilöllisestä näkökulmasta pikemminkin jälkituotannollisen kulutuksen kohteeksi ja elämysten lähteiksi (vrt. Rannikko ym. 2015). Nämä edellä esitetyt esimerkit näyttävät vahvistavan tarinaa, joka kertoo ihmisten irtautumisesta materialistisista arvoista.

Nähdäkseni vain lopulliseen hyötyyn keskittyminen on ongelmallista luontosuhteen erityyppisten materialistisuuksien näkökulmasta, koska silloin ei tule esille se, miten luontomateriaalia hyödynnetään materiaalittoman toiminnan mahdollistamiseksi. Käyttämäni logiikka perustuu yleisemmin hyvinvointikeskustelussa käytettyyn tulkintaan materialistisista resursseista ihmisten toimintaa mahdollistavina elementteinä (vrt. Sen 1993; Hirvilammi 2015, 24-28). Materialistiset resurssit, kuten tässä artikkelissa ihmisten hyödyntämät luontomateriaalit, määrittyvät tällöin välinearvoiksi, joiden avulla päästään hyvinvointia lisäävään päämäärään (Atkinson ym. 2012, 2). Riippumatta siitä, onko tavoiteltu päämäärä materialistinen vai materiaaliton, tulkitsen luonnon materiaalisten elementtien kuluttamisen ja muokkaamisen keskeiseksi osaksi sitä prosessia, jonka myötä maisema materiaalisena muotona ihmisen arkielämässä muuttuu (vrt. Tanskanen 2000, 44). Maiseman materiaalisten elementtien näkeminen merkityksellisinä on erityisesti kylämäisissä luontoympäristöissä tärkeää, kuten Uusitalo (2020, 13, 31) tuoreessa väitöskirjassaan esittää. Tästä esimerkkinä voidaan hyödyntää Rivalin (ks. Venkatesan ym. 2018, 45) tulkintaa metsästä polkuineen ja jokineen luontomateriaaleista koostuvana infrastruktuurina, joka mahdollistaa ihmisten kulkemisen. Metsän luontoelementit eivät siten tulkintani mukaan ole vain itsearvoisesti olemassa vaan välineellisinä materiaaleina ihmisten toiminnan mahdollistajina tai rajoittajina.

Tätä toiminnan kautta määrittyvää materialistisuutta tulkitessani olen erotellut välillisen/ välineellisen (instrumental) ja lopullisen (intrinsic) arvon toisistaan. Materialismeja koskevan analyysin kannalta pidän sopivana O'Neillin (1993, 8-9) erottelua, jonka mukaan jollakin objektilla, kuten luonnonvaralla, on instrumentaalinen eli välillinen tai välineellinen (mean) arvo, mikäli sen välittämänä päästään johonkin lopullisesti (end) tavoiteltuun arvoon (intrinsic). On kuitenkin huomioitava, että jokin objekti voi olla myös itsearvoisesti olemassa (myös intrinsic) ilman, että siihen liittyisi suoraa hyötyarvoa (O’Neill 1993, 8-9). Artikkelissani korostuvan ihmiskeskeisen hyötyarvon johdosta jälkiteollisia materialismeja koskevat tulkintani keskittyvät välillisen arvon ja lopullisesti tavoitellun hyötyarvon erotteluihin sekä niiden väliseen suhteeseen. 
Artikkelin analyysissa määritän luontosuhteen materialistiseksi ensinnäkin silloin, kun luontoa hyödynnetään fyysisesti materiaalisena resurssina - siis kulutetaan tai suoranaisesti muokataan luonnon materiaalisia elementtejä - joko välillisesti ja lopullisesti. Määritän luontosuhteen siten materialistiseksi myös silloin, kun lopullinen hyöty olisi materiaaliton. Lisäksi määritän luontosuhteen epäsuorasti materialistiseksi silloin, kun luonnosta saatavan hyödyn - olipa lopullinen hyöty luonnosta sitten materialistinen tai materiaaliton edellytyksenä on jonkin materiaalisen hyödykkeen käyttäminen tai sen kanssa toimiminen.

Erilaisten hyötyjen ja materialismikytkösten monimuotoisuuden havainnollistamisessa olen hyödyntänyt kahta lähestymistapaa, joista sommittuma (assemblage) palvelee samoihin luontoelementteihin kohdistuvien erityyppisten hyödyntämismahdollisuuksien analysointia ja metsäsuhteiden moninaisuus puolestaan yksilöllisten luontosuhteiden materialismien erottelua. Woodsin $(2016,30)$ muotoilemassa määritelmässä sommittuma muodostuu materiaalisista elementeistä sekä niitä ilmentävistä ekspressiivisistä olomuodoista. Konkreettisena esimerkkinä Kortelainen ja Albrecth $(2019,139)$ esittävät savuvanaiset tehtaanpiiput, jotka näkökulmasta riippuen voivat ilmentää teollisuusmaisemaa tai haisevia ilmansaasteita. Sommittuman on tässä artikkelissa ymmärretty muodostuvan luontomateriaaleista, jotka saavat erilaisia merkityksiä ekspressiivisten olomuotojensa eli erilaisen arvottamistapojen myötä.

Metsäsuhteiden moninaisuudessa nojaan Kietäväisen (2011, 45-46) havaintoihin. Hänen mukaansa metsän merkitys voi ilmetä samanaikaisesti taloudellisena, toiminnallisena ja henkisenä suhteena. Tätä logiikkaa soveltaen tulkitsen, että esimerkiksi luontomatkailusta elantonsa saava elinkeinonharjoittaja voi samaan aikaan saada luonnosta sekä materialistista hyötyä rahana että materiaalitonta virkistäytymistä ja henkistä hyvinvointia.

\section{Tapaustutkimus monitoiminnallisesta maisemasta}

Tutkimus on toteutettu tapaustutkimuksena, jossa monitoiminnallista maisemaa on tarkasteltu arkitodellisuuden kautta (vrt. Yin 2003, 13). Termi 'tapaus' viittaa maantieteellisesti rajattuun ilmiöön, josta voidaan tehdä havaintoja tiettyyn aikaperspektiiviin sidottujen hetken kuvausten avulla (ks. Gerring 2007, 19). Tässä tapauksessa luonnonvarojen arvottamista ilmiönä on tarkasteltu maantieteellisesti rajatulla alueella Lieksan itäisissä osissa 2010-luvun alkupuolella. Ajankohta on erityinen siksi, että tuolloin luonnonvaroihin liittyvä keskustelu oli jo voimistunut, mutta ei leimallisesti rajoittunut erityisiin konflikteihin. Tiettyyn paikkaan kiinnittyvän tapaustutkimuksen avulla on ollut mahdollista löytää syvällisiä kuvauksia yleisesti havaittavasta ilmiöstä (Stake 1995, 3) ja tapaustutkimuksille tyypillisesti olen pyrkinyt ymmärtämään ilmiötä erilaisten prosessien muodostamana kokonaisuutena (Häikiö \& Niemenmaa 2007). Intensiivisen tapaustutkimusperinteen mukaisesti olen kiinnittänyt huomiota siihen, miten arvojen kerrostumat ovat muodostuneet ja miten erilaiset toimijat ovat kerrostumiin vaikuttaneet (ks. Sayer 1992, 242-243; Clifford ym. 2016, 13).

Tarkastelun kohteena oleva luonnonvara-alue muodostuu valtion talousmetsistä, retkeilyalueesta ja luonnonsuojelualueista sekä metsäyhtiöiden, kunnan ja yksityisten maanomistajien maista (Kuva 1). Alueen keskelle sijoittuva retkeilyalue on kartan luokituksessa laskettu mukaan valtion metsämaihin, joiden sisällä sijaitsee myös pistemäisiä vanhojen metsien suojeltuja alueita (ks. Rannikko \& Tervo 2006, 326). Retkeilyalue ja luonnonsuojelualueet ilmentävät horisontaalista tapaa jäsentää monimuotoista maisemaa, jolloin eri alueet on pyhitetty tietyille toiminnoille, kun taas muut alueet kuvastavat paremmin vertikaalisesti monitoiminnalliseksi miellettyä maisemaa (vrt. Nijnik ym. 2010, 342-342).

Monitoiminnallinen metsämaisema muodostuu metsästä, maisemasta ja metsämaisemasta. Metsään viittaan erityisesti silloin, kun kyse on konkreettisesta metsästä. Maisema puolestaan viittaa tulkinnassani ennen kaikkea teoreettiseen käsitteeseen, kun taas 
haastateltavien puheessa maisema kiinnittyy rajatumpaan näkökulmaan koskien erityisesti visuaalista näkymää ja estetiikkaa. Näiden kuvausten jatkeeksi haastateltavat kuitenkin kuvaavat myös monimuotoista toimintaa, jota tulkitsen teoreettisempaa maisemakäsitettävä vasten. Metsämaisema taas spesifioi, millaisesta maisemasta olen kiinnostunut ja asettaa maiseman tarkastelun erityiseen kontekstiin kuten esimerkiksi Tanskasen (2000) käyttämä 'suomaisema' tai Pitkäsen (2011) 'mökkimaisema'.

Kartta-aineistojen, kenttäkäyntieni ja empiirisen tutkimusaineistoni perusteella olen muodostanut tutkimusalueesta seuraavan kuvauksen. Metsämaisemaa raamittavat havupuuvaltaiset metsät, kumpuilevat mäet, koskimaiset joet ja suoalueiden ympäröimät järvet, joita petoeläimet karhuista susiin täydentävät. Luonnonvaraksi määrittyvä lähimetsä alkaa käytännössä asukkaiden pihalta. Reitti syvemmälle metsään jatkuu läpi polkujen, metsäautoteiden ja jokien. Aluetta kuvaavat yhtä lailla erämaamaisuudelle tyypilliset piirteet luonnontilaisuudesta harvaan asutukseen (vrt. Hallikainen 2001) kuin tuotantokäyttöön hyödynnettävä talousmetsä. Toisin kuin Vaaran ja Saastamoisen $(2006,350)$ janamallissa, etäisyys asuinympäristöstä talousmetsiin ja edelleen erämaihin ei näyttäydy etäisenä vaan arkisen läheisenä. Tulkitsen nämä luonnonvara-alueet ihmisen ja luonnon vuorovaikutuksessa syntyneeksi toiminnalliseksi eli ekspressiiviseksi maisemaksi, johon kuuluvat materiaaliset elementit kuten maalajit, vesistöt ja rakennukset samoin kuin eliöt kasveista eläimiin (vrt. Malpas 2011, 14-21; Woods 2016). Alueesta on ajan kuluessa muodostunut monitoiminallinen maisema niin luonnollisten kuin sosiaalisten toimintojen näkökulmasta (vrt. Gulinck 2004).

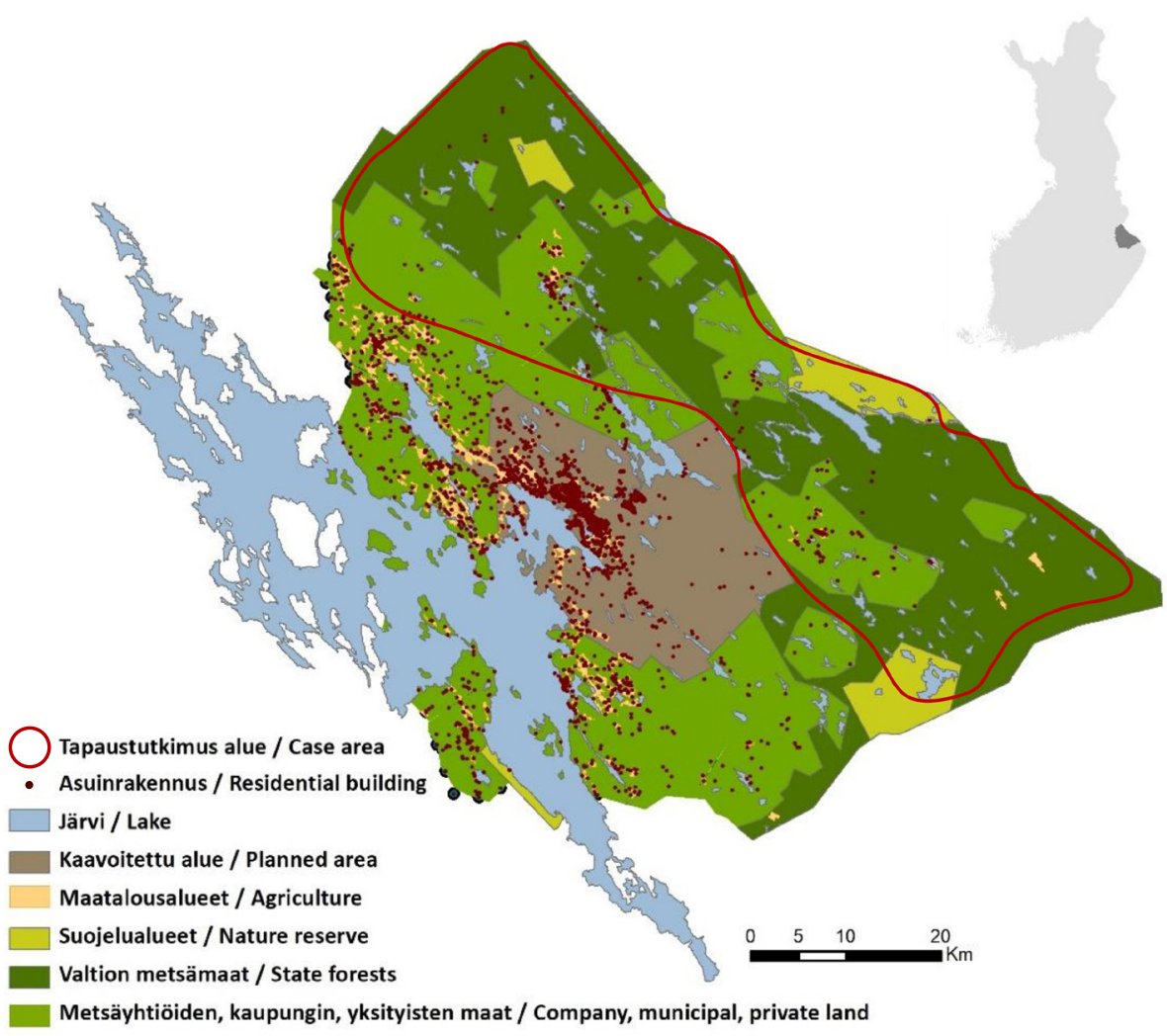

Kuva I.Tapaustutkimusalueen rakenne.

Figure I. Structure of the case study area.

Aineisto/Data: SYKE 2008; MLL 20II;VRK 20II; MLL \& Ek 2016 


\section{Arjen kertomuksista materialismitulkintoihin}

Tutkimuksen aineisto muodostuu alueella arkeansa eläneiden asukkaiden haastatteluista. Arkisten kokemusten ja arvojen kuvausten myötä tulkitsen haastatteluja kertomuksina (vrt. Laurén 2009). Kertomushaastatteluiksi nimeämistä perustelee se, että valtaosa haastattelujen sisällöistä on kertomuksen muotoon puettuja kuvauksia elämään liittyvästä kokemuksellisuudesta sekä paikoin myös elämän yllätyksellisyydestä (ks. Hyvärinen 2017, 177). Vuosina 2010-2013 toteutettuja haastatteluja on yhteensä 17, joista neljä on tehty parihaastatteluna. Näin ollen haastateltavia on yhteensä 21. Haastatteluista neljä olen tehnyt tutkija Eero Vatasen kanssa yhdessä ja loput olen haastatellut yksin. Miellän haastateltavat heterogeeniseksi ryhmäksi, johon sisältyy eri ikäisiä aikuisia (nuorin 28, vanhin 69 vuotta), miehiä (8) ja naisia (13), syntyperäisiä asukkaita (8) ja tulomuuttajia (13), syntyperältään suomalaisia (15) ja ulkomaalaistaustaisia (6) sekä luonnonvaroja taloudellisesti (9) ja ei-taloudellisesti (12) hyödyntäviä. Yhteistä heille on, ettei yhdenkään haastatellun päätoimeentulo tai -työ ollut perinteisen metsätalouden tai -teollisuuden piirissä. Näin ollen tulkitsen haastateltavien edustavan ryhmää, joiden toiminta metsämaisemassa kohdistuu ensisijaisesti jälkiteollisiin tapoihin. Tutkimusaineisto tuo esiin haastateltujen asukkaiden näkemyksiä ja pohdintoja metsien hyvin moninaisista käyttömuodoista siellä, missä kansallisestikin merkittävät metsävarat sijaitsevat. Pieniä episodimaisin ja kertomuksellisin esimerkein esitettyjä kuvauksia yhdistelemällä (vrt. Estola ym. 2017; Hyvärinen 2017) olen pyrkinyt luomaan monimuotoisen tulkinnan luonnonvarojen arvottamisesta ja materialismeista.

Artikkelissa käytetyt haastattelut ovat osa laajempaa haastattelukokonaisuutta, jossa kartoitettiin haastateltavien arkea asuinpaikkahistoriasta asuinympäristön kehittämistä koskeviin kysymyksiin. Haastateltavilta kysyttiin yhtenä kysymyksenä, millainen merkitys heitä ympäröivällä luonnolla on heidän elämässään. Näissä vastauksissa tuli kaikkein yleisemmällä tasolla esille erilaisia tapoja hyödyntää tai muutoin arvottaa luontoympäristöä. Yleisiä kuvauksia tarkempia ja analyysin kannalta mielekkäimpiä kertomuksia arvottamisesta, kokemuksista, konflikteista ja kerrostumista tuli esille muihin arjen osiin ja elämäntarinaan liittyvissä kysymyksissä. Artikkelin analyysin kannalta keskeisimmät kysymykset koskettivat haastateltavien asuinpaikan valintaa, elinkeinoja, vapaa-aikaa ja harrastuksia, paikallista yhteistyötä sekä asuinympäristön vahvuuksia, mahdollisuuksia ja uhkakuvia.

Koko haastatteluaineisto on litteroituna 302 sivua (riviväli 1, fontti 12). Olen lukenut kunkin haastattelun ensin kokonaisuudessaan kerran. Seuraavassa vaiheessa olen poiminut luennan yhteydessä kustakin haastattelusta luontosuhteita ja -näkemyksiä kuvastavat lainaukset, minkä jälkeen olen suorittanut vielä tarkastusluennan tarkastuspoimintaa varten. Tämän jälkeen olen yhdistänyt artikkelin analyysia varten poimitut haastatteluaineistot (yhteensä 55 sivua). Nämä haastateltavien sitaatit muodostavat rungon artikkelissa käytetylle perinteiselle tekstimuotoiselle sisällönanalyysille (ks. Krippendorff 2004, 18). Englanninkieliset sitaatit olen kääntänyt artikkelia varten suomeksi. Poikkeuksellisesti näitä sitaatteja ei ole merkitty erikseen haastateltavien anonymiteetin säilyttämiseksi. Katsoin tämän tarpeelliseksi, koska sitaattien sisällön ja englannin kielen käyttämisen yhdistelmällä anonymiteetti voisi vaarantua. Haastateltavat on pseudonymisoitu koodein H01-H21.

Analyysissa on syytä erottaa erilaiset analyysin tasot, joiden erottelemiseksi olen soveltanut Karjalaisen (1995, 17-19) kolmea lukutapaa: realistinen, humanistinen, poststrukturalistinen. Karjalaisen alkuperäisessä jäsennyksessä realistinen lukutapa tähtää kuvitellun tai olemassa olevan reaalisen maiseman fyysiseen kuvaamiseen. Humanistinen puolestaan tarkastelee, miten maisema koetaan, tulkitaan ja arvotetaan elämismaailmassa. Post-strukturalistinen lukutapa asettuu näiden jatkeeksi korostaen lukijan ja tekstin välistä yhteyttä sekä merkitysten tuottamisen tapaa. Tässä tutkimuksessa realistinen lukutapa kiinnittyy siihen, että aineistoissa kuvatut elämismaailman tapahtumat tapahtuvat todelliseksi miellettävässä reaalisessa maisemassa, jota haastateltavat itse kuvaavat 
ja jota voidaan havainnollistaa esimerkiksi kartta-aineistoin. Aineistojen analyysissa huomio kuitenkin kiinnittyy kulttuurimaantieteelle tyypillisimmin (ks. Pitkänen 2011, 22) haastateltavien esittämiin kokemuksiin ja tulkintoihin tästä olemassa olevasta maisemasta. Asukkaat itse puhuvat eksplisiittisesti asuinympäristönsä luonnon erilaisista käyttötavoista ja arvoista sekä näkemyksistä, jotka kuvastavat luonnon merkitystä heidän arjessaan. Nämä haastateltavien humanistiset kertomukset puolestaan muodostavat pohjan post-strukturalistiselle analyysilleni erilaisista materialistisista luontosuhteista monitoiminnallisessa metsämaisemassa. Tulkinnat materialismeista ja käsitteellisestä maisemasta eivät siten ole haastateltavien itsensä esittämiä vaan heidän lausumiinsa perustuvia omia tulkintojani.

\section{Talousmaisema näyttämönä - suojelumaisema ideaalina}

Metsätalouden merkitys maisemaa muokkaavana käyttötapana näkyy haastatteluissa edelleen vahvana. Vanhimpien haastateltavien kertomuksista välittyi kuitenkin metsätalouden muutos, minkä vuoksi hakkuiden laajuus ja erityisesti merkitys toimeentulon turvaajana näyttää menneisiin vuosikymmeniin verrattuna vähäisemmiltä:

"Nyt ne suuret savotat obi jo, että ei siellä savottoja nïn rankkoja, isoja oo, kuin mitä ennen oli. Kun on kaikkki, Metsähallituksenki metät kertaalleen hakattu käytännössä. Sitä kesti viis-kunskymmentä vuotta, vaan siellä uus mehtä on kasvanu. [...] Vähentyny nün paljon se ihmismäärä, että viis-kuuskytluvulla, kenties talviaikana, nïn tuhansia ibmisiä täälä. Ensin asukkaita ja sitten kaikkei mebtäkämpät täynnä savottalaisia." (H17)

Artikkelin kertomuksissa ihmisten harvasti asuttama ja materialistisesti teollisuutta varten muokkaama talousmetsä asettautuu näyttämöksi erämaan arvoille kuten puhtaudelle ja neitseellisyydelle villipetojen olemassaoloa unohtamatta:

’Vabvuntena pidän tätä pubdasta luontoa ja erämaata. Tää on säilynnä, vaikke noita punviljelyksiä mebtä täynnä, nün kuin minä sanon näitä hakkuupalstoja, kuin mäntypeltoja. Kummiski aika neitseellistä aluetta. [...] Sudet on vissiin bävinnä, mutta karbujen kannalta ja muntenki metsänelläinten, villipetojen ja muittenkin elänten puolella tää on byvin tibheesti asuttuu.” (H07)

Mäntypeltojen ja hakkuupalstojen täyttämä kuvaus on kuitenkin vastoin erämaisuuden ideaalia ja mukautuukin hyvin Hailan (2003, 183-186) esittämään kritiikkiin ihmisen ulkopuolisesta erämaasta. Esimerkki havainnollistaa hyvin sommittuman ekspressiivisen luonteen moninaisia merkityksiä (vrt. Kortelainen \& Albrecth 2019). Tämä alun perin perinteistä materialistista tarkoitusta varten kasvatettu talousmetsä voi yhdelle merkitä vain hyödykkeitä varten kasvavaa materiaalia, toiselle edustaa luontevaa osaa neitseellistä erämaata ja Milbournen ym. (2008) mukaisesti kuvautua virkistyskäytön poissulkevana talousmetsänä.

Ihmistoiminnan ulkopuoliseksi alueeksi mielletty luonnonsuojelualue puolestaan näyttäytyy kertomuksissa rauhoittavana vastapainona talousmetsälle, vaikka tässäkään tapauksessa luonnonsuojelualuetta ei voi pitää historialtaan ihmiskäsin koskemattomana (vrt. Haila 2003, 186). Luonnonsuojelualue kuitenkin esitetään mahdollisimman itsearvoisesti olemassa olevana luontona, mihin on vaikea kytkeä materialistisia merkityksiä. Katsominen reunasta ja tietoisuus suojelualueen olemassaolosta on riittävää. Materialistinen yhteys on kuitenkin epäsuorasti löydettävissä alueen reunalla sijaitsevasta asumuksesta. Asuintalo edustaa materialistista hyödykettä, jonka avulla tästä materiaalittomasta kokemuksesta voidaan arkipäiväisesti nauttia. Suojelualueesta näyttää olevan myös hyötyä kokijalleen, koska se tasapainottaa teollisesti materialististen käyttötapojen siedettävyyttä asuinympäristön muissa osissa: 
"Aiemmin olin huolissani tästä ympäristöstä. Mutta siitä lähtien kun olemme asuneet täällä, aina kun katson ikkunasta järven yli ja näen luonnonsuojelualueen. En katso taakse, en välitä, koska tiedän että meillä on [luonnonsuojelualue] tuolla. [...] Tämä iso luonnonsuojelualue ilman mitään metsänhoitotoimenpiteitä tai vaellusreittejä on todella koskematon. [...] Me emme käytä sitä, mutta vain se tietoisuus sen lähellä olemisesta on fantastista." (H12)

\section{Kaupungin materialismeista kohti luontokokemuksia}

Luontosuhdetta kuvaavat kertomukset lähtevät liikkeelle asuinympäristön erityispiirteiden kuvaamisesta, joissa korostuu maiseman estetiikka: "Erämaajärvet, pienet tuolla nebän on aivan fantastisia. [...] Kyllä se kuitenkin semmonen vaaramaisema oltava." (H06) ja erityisesti sen kauneus katsojan silmissä: "Kyllähän tämä nïn kuin näet, nïn luonnonkaunis paike.e." (H17). Asuinympäristön eduksi koetaan, että 'Luonto on lähellä" (H03), varsinkin kun sen vahvuuksiksi arvioidaan "Pubdas luonto, rauballisuus ja biljaisuns." (H14). Nämä aistimukset ja tuntemukset kietoutuvat toisiinsa: "Tämä tila tekee tästä nïn kaunïn ja ibmeellisen, [...] hiljaisuns ja villi tila.” (H11) ja edellyttävät monille kaupunkiympäristöille tyypillisten ominaisuuksien puutetta: "Tää väliyys, tää luonto, tääl ei oo ibmisiä, tääl ei oo liikennettä, ei oo lentoliikennettä. Siis yleensäkin et tääl on biljasta." (H16).

Nämä maisemat ovat fyysisesti olemassa ja ne voidaan kokea erilaisin aistein, mutta materialistista käyttöä tai suoraa kosketusta edellä luetellut luontokokemukset eivät edellytä. Oikeaksi koetun luonnon keskellä elämisen koetaan herättävän yhtä aikaa vaarantuntua ja turvallisuuden tunnetta sekä johtavan luonnollisten vaistojen heräämiseen ja lopulta luonnon kunnioittamiseen:

"Kiehtoo se vaara [...] että mä tiedän, että me voitas oikeesti, kun kävellään tosta rantaan, törmätä karbunn siinä matkalla tai että täällä on susia. Totta kai tiedän, että me ollaan aika turvassa [...] Mua kiebtoo se, että tässä on oikeaa luontoa. [...] Mun mielestä myös ibminen on paremmin turvassa, jos sillä on vielä jäljellä semmosia vaistoja ja viettejä, joita sellanen oikeea luonto voi herättää ibmisessä. [...] Se luonto on nyt tossa, jota pitää arvostaa tai munten käy buonosti.” (H10)

Kertomukset vahvistavat Inglehartin ja Bakerin (2000) havaintoja hyväosaisista nykyihmisistä, joiden fyysiset perustarpeet vaikuttavat tulleen täytetyiksi. Materiaalisten hyödykkeiden ja jopa perinteisen virkistystoiminnan sijaan hyvinvoinnin edistämistä etsitään jostain vieläkin materiaalittomammin määrittyvistä lähteistä:

"Perustarve tulee tyydytetyksi jo varmaan suurimmalla osalla. Mutta mikä on se benkinen tarve? Sitähän on birmu vaikee sanoa. Voi sitä vähän aistii kirjotuksista ja ihmisten pubheista, mikä ois se mitä [uonnosta] kaipais. [...] Minä uskon, että benkisellä puolella on kuitenkin jotabin semmosta, muutabin kuin tätä metsästystä ja kalastusta.” (H18)

Jännite materialistisesti tuotettujen hyödykkeiden ja vähemmän materiaalikeskeisen elämäntavan ideaalin välillä on vahvasti läsnä haastatteluissa. Kertomuksista on löydettävissä yhteys Curtinin ja Kraghin (2014) luontomatkaajiin, Fletcherin (2009) ekoturisteihin sekä Rannikon (2008, 93-94) ja Kortin $(2011,35)$ esittämiin pistäytyjiin, jotka pyrkivät paikkaamaan luonnosta irtaantumistaan lyhytaikaisilla vierailuilla. Näille pistäytyjille paikalliset matkailuyrittäjät tarjoavat sitä, minkä he itse kokevat luontoympäristössään materiaalittomasti nautittavana ja tätä luontoympäristöä hyödyntäen ansaitsevat itselleen materialistista hyötyä rahana:

"Voi asua tällaisen luonnon keskellä. Minulle se on luksusta, koska on rauhallista, terveellistä, sïtä voi nauttia. Ja tästä me yritämme tehdä bisnestä.” (H20) 
Tutkimukseen haastatelluille muuttajille kyse on pysyvämmästä muutoksesta. Kärjekkäimmissä ilmaisuissa kaupungin rakennettu maisema ja luontoympäristöksi tarkoitettu puistokin ilmentävät ahdistavaa, materialistisesti muokattua asuinympäristöä. Harvaan asuttu metsä vailla keinotekoisiksi koettuja kaupungin rakenteita ja niissä vilistäviä kulkuneuvoja kuvastaa puolestaan paikkaa, jossa on tarjolla ajatuksetkin kirkastavaa mielenrauhaa:

"Halusin paikekaan, jossa voin mennä kymmenen minuuttia ja sit oon metsässä. En halua, että on joku iso puisto, missä on polkupyörät. [...] Siellä [kaupungissa] on [...] betonit, asfaltit ja sit koneet kulkevat edestakaisin. [...] Siellä ei voi ajatella.” (H19)

Vaikka kaupungin rakenteista ja hyödykkeistä etäännyttämisen tarve esiintyvät leimaavasti haastateltavien kertomuksissa, kyse ei kuitenkaan ole sinänsä materialistisista tarpeista irtautumisesta. Arkea eletään kaupungin ostoskeskusten luomaan ympäristöön nähden vähemmän materialistisena näyttäytyvän luonnon keskellä, josta voi kuitenkin tarvittaessa piipahtaa kaupunkiin materialististen kulutushyödykkeiden äärelle:

"Kyllä se oli ihan ebdoton, että sieltä bullunmyllystä piti päästä pois. [...] Kun on kumminkin luonto tämmönen, täällä lähellä. [...] Totta kai tykkään, kun Helsinkiin meen käymään, että meen kauppakeskukseen. Mutta en balua, että se on mun normaalia arkea." (H02)

Kertomukset kuvastavat haastateltavien pyrkimyksiä parantaa subjektiivista hyvinvointia ottamalla etäisyyttä materialistisesta tarjonnasta, mikä sinänsä heijastelee Inglehartin ja Bakerin (2000) esittämiä hyvinvoinnin materialistisia muutoksia. Haastattelujen perusteella olisi kuitenkin hurskastelua väittää, että erämaisessa luontoympäristössä asuminen irtaannuttaisi automaattisesti materialistisesta elämäntavasta. Juuri materialistisen sivilisaation suhteellinen läheisyys tekee erämaisessakin luontoympäristössä asumisen mutkattomaksi:

"Kunlostaa paradoksiselta. Me asumme ikään kuin erämaassa, mutta silti meillä on kaikki jokapäiväisessä elämässä tarvittava saatavilla 30 kilometrin säteellä. [...] rakennusmateriaalit, maalaustarvikkeet, asumiseen ja ruokaan tarvittavat tarvikkeet, kaikeki.” (H21)

Tutkimusalueen kaltaisen arkisen erämaisen luontoympäristön ajatellaan ennemmin tarjoavan vastapainoa materialistisille virikkeille. Luonnon fyysisen lähietäisyyden arvioidaan edesauttavan luonnon vuodenkierron tunnistamista: "Keväälä joutsenet ja kurjet tulee ajallaan. Ne tuossa pellolla on, huutaa ja tanssii. Sitä pidetään ihan luonnollisena." (H17) ja ylipäätään luonnonkierron ja olioiden olemassaolon tarkoituksen tiedostamista:

"Vanhempana haluan välittää sellasia arvoja kuin luonto ja sen luonnon tunteminen. Monet kaupunkilaislapset pelkää metsässä, ne pelkeää kaikkkia eläimiä, pelkeää kaikkia byönteisiä, koske ne on niille ihan outo asia. [...] Hyttyset on ärsyttäviä, [mutta] byttyset pitää olla olemassa, koska sudenkorennot syö niitä ja pikekuöttiäisiä on, koska linnut syö niitä. Puut on siksi, että niistä tulee ilmaan happea. Sellasia ihan normaaleja luonnonarvoja, mitkä ei välttämättä tulisi ajankohtaiselesi, jos asuisi Helsingin keskustassa.” (H10)

Näihin arvottamisen muotoihin ei liity materialistisia tapoja hyödyntää luontomateriaaleja vaan pikemmin pyrkimys ymmärtää luontoa itsearvoisesti olemassa olevana edellyttäen kuitenkin suoraa aistiyhteyttä luontoon. Pitkään kestäneen luonnon lähellä asumisen kääntöpuolena merkityksellisetkin piirteet näyttävät hiipuvan itsestäänselvyyksiksi, joita ei enää ilman ulkopuolisten ihmettelyä itse havaita - olipa kyse luonnon herättämistä miellyttävistä tuntemuksista: "Kyllähän tämä meidän luonto, rauba ja biljaisuus, kyllä se on 
tärkeempi kuin mitä me itse sitä arvostetaan.” (H15) taikka itselle tavanomaisten luonto-olioiden arvon tunnistamisesta missä tahansa muodossa:

'Tuossa on koivu, mänty ja kuusi. [...] Joillekin, jotka asuu suuressa kaupungissa eikä ole nähneet suurta kunsta, ne voi olla erityisiä. Täällä kun menet ulos, näet niitä miljoonan. Sinulle siinä ei ole mitään ibmeellistä vaan normaalia etkë sitten näe niiden arvoa." (H20)

\section{Luonnonantimien ja virkistyksen kudelma}

Siitäkin huolimatta, että haastateltavien toiminnot metsämaisemassa kuvastavat ensisijaisesti jälkiteollisia muotoja, heidän luontosuhdettansa ei voi määritellä täysin materiaalittomaksi. Tutkimuksen kertomuksissa on ensinnäkin viitteitä samoista materialistisuuden perusteista lähtevistä tavoista käyttää puuta omiin materialistisiin tarpeisiin kuin mihin metsäteollisuuden määrittely materialistisena nojaa (vrt. Haila 1990; Mather 2001). Haastateltavilla käyttötarve kuitenkin ilmentää ennen kaikkea luontaistalouden muotoja (ks. Kangas \& Kokko 2001). Asuntojen lämmitys puulla on näistä konkreettisin esimerkki, jota varten puuta on luonnollisesti kaadettava ja pilkottava: "Talvella lämmittää [...] viiskytä mottia puita haloin, pilkekeeksi." (H17) Osa lämmityspuista on muualta ostettuja, mutta osa kaadetaan lähimetsästä: "Keväällä osti puita, siinä vaibeessa kun ne alkooi olla loppu. [...] Me myös kaadettiin tosta metsänlaidalta vähän metsää." (H10), tyypillisimmin omasta: "Metsästä raivoominen, puun kaataminen, kun omasta metästä ottaa ne.” (H18). Samaa metsäteollisuuteen liitettyä materialismin logiikkaa noudattaen kaadetut puut eivät ole itsearvoisesti vaan välinearvoisesti olemassa materialistista loppuhyötyä varten. Puu on välillisesti olemassa pilkettä varten ja pilkottu pilke on jo itsessään hyödyke, minkä lisäksi lämmitystarve fyysisenä perustarpeena entisestään vahvistaa loppuhyödyn materialistisuutta (vrt. Inglehart \& Baker 2000).

Siinä missä metsäteollisuuden materialistisuuden kulminaatiopiste ilmenee puusta jatkojalostettuna loppuhyödykkeenä, yhtä lailla puusta voidaan jatkotyöstää loppuhyödykkeitä muihinkin materialistisiin tarpeisiin:

"Kerään luonnosta puita, esimerkiksi majavan bylkäämiä. [...] En ole itse tehnyt [näitä pöytiä ja tuoleja], mutta mä oon keränny keppejä [tai pikemminkin pöllejä] ja sit ybdelle kaverille kertonut, mitä haluan." (H19)

Materialistisen hyödykeperusteen näkökulmasta on yhdentekevää, onko jatkojaloste ihmisen itselleen tekemä vai teollisuuden kautta tuotettu. Puuta voidaan kaataa kumpaan tahansa tarkoitukseen - skaala ja välivaiheet vain poikkeavat. Yksityishenkilöt harvemmin myöskään omaa jatkojalostustarvettaan varten kasvattavat tietynlaisia puita, mutta ei sekään mahdoton ajatus ole. Luonnostaan kaatuneiden tai eläinten hylkäämien puidenosien hyödyntäminen sitä vastoin ei edellytä luontomateriaalin irrottamista ihmisen vuoksi. Silloin yksi ihmisen aiheuttama materialistinen välivaihe vähenee, joskaan luontoon puumateriaali ei poiston jälkeen yleensä palaudu.

Jälkiteollista elämäntyyliä kuvaavat erityisesti erilaiset aktiviteetit, jotka haastateltavat liittävät virkistäytymiseen ja harrastamiseen sekä matkailuyrittäjien tapauksessa osin työn lomassa tapahtuvaksi toiminnaksi. Matkailuyrittäjät tarjoavat pitkälti samoja aktiviteetteja myös asiakkailleen, minkä lisäksi asukkaat mainitsevat eri vuodenaikoina pistäytyviä virkistäytyjïä (vrt. Rannikko 2008; Kort 2011). Luonnon läheisyys ja siellä risteilevät reitit näyttävät muodostavan keskeisen osan tarvittavasta luonnon infrastruktuurista (vrt. Rival, ks. Venkatesan ym. 2018) ja nousevan tärkeimmiksi edellytyksiksi erilaisten aktiviteettien luo pääsemiseksi tai niiden toteuttamiseksi: 
’Minkä takia minä tykeään asua täälä, on just tää luonto. Se on tässä nïn lähellä [...] Täältä löytyy rantoja ja paikkoja, missä uida. [...] lenk.keillä, kävellä. [...] Onhan täällä polkuu ristiin rastïn ihan älyttömästi.” (H01)

Luontoympäristöön liittyviä aktiviteettimahdollisuuksia voi kuvata haastattelujen perusteella kattaviksi. Edellä mainittujen uimisen, lenkkeilyn ja kävelyn lisäksi aktiviteetteihin kuuluvat "ratsastus ja lumikenkäily, nuotioruokailu" (H11), "retkeily ja vaeltaminen, pyöräily sekä kanootilla melonta" (H21). Haastateltavat kertovat aktiviteettimuotojen ohessa liikkumistavoistaan "Luonnossa tulloo aika paljon liikuttun koirien kanssa ja sienestettyy." (H03) ja kuvaavat aktiviteetteja, joista pitävät "ainakin moottorikelkkailusta ja metsästyksestä, kalastuksesta” (H02). Tälle alueelle tyypillisenä mutta muutoin hieman erityispiirteisempänä aktiviteettina haastatteluissa nousevat sekä yksittäisten asukkaiden että matkailuyrittäjien koirat "on koiravaljakkkoyrittäjää, matkailuyrittäjää" (H07), joita ylläpidetään rekiajeluita varten: "Mekin ajetaan talvella noilla rekivaljakoilla." (H10).

Luokittelen kaikki edellä mainitut aktiviteetit jälkiteolliseen metsänkäyttöön kuuluviksi niihin liitetyn virkistysarvon myötä ja siten lopulliselta hyödyltään materiaalittomiksi. Näihin virkistäytymisen muotoihin on kuitenkin kytkettävissä vähintäänkin välillisesti materialistisia resurssiarvoja, joiden avulla lopulliseen päämäärään eli virkistystäytymiseen päästään (vrt. Atkinson ym. 2012).

Vapaa-ajallaan marjastava matkailuyrittäjä kuvastaa metsäsuhteen moninaisuutta parhaimmillaan. Metsän eri merkitykset raaka-aineesta ja rahan lähteestä työhön ja vapaaaikaan kytkeytyvät erottamattomasti toisiinsa (vrt. Kietäväinen 2011):

"Vapaa-ajaksi koen marjastuksen. [...] Mutta sïnäkin on taas se, että se on tietyllä tavalla työtä, että käytän kaikki marjat tässä meidän [yritykesessä], käytän asiakkaille. Itse poimituista mebut, hillot ja munt. Mut koen kyllä vapaa-ajaksi sen keräämisen.” (H16)

Jos vapaa-ajalla suoritettavan tekemisen voi luokitella virkistykseksi, niin luonnossa tapahtuvan keräämisen voi tulkita johtavan virkistäytymiseen ja siten luonnon välityksellä saatuun materiaalittomaan kokemukseen. Muilta osin luonnon materialistista arvoa on tässä tapauksessa mahdoton sivuuttaa. Kerätyt marjat samoin kuin sienet itsessään ovat luontoon jäädessään maatuvaa ainesta, mutta kerättyinä luonnosta poistettua ihmisen fyysisiä tarpeita tyydyttävää materiaalia. Marjat ovat siten materialistisia loppuhyödykkeitä tulipa marjat sellaisenaan nautituiksi taikka mehuiksi ja hilloiksi jalostetuiksi. Asiakkaita varten kerättyinä ja tarjottuina ne liittyvät myös työhön ja sen myötä edelleen taloudelliseen hyötyyn. Tällöin luonnon marjat ovat välillinen materialistinen resurssi, joiden avulla voidaan saavuttaa lopullinen materialistinen hyöty rahana.

Metsästyksen ja kalastuksen logiikka on materialistisuudeltaan samantapainen kuin marjastuksessa ja sienestyksessä. Samat villieläimet, jotka edellä esitetyssä maisemallisessa sommittumassa asuttivat itsearvoisina olentoina erämaata, saavat käyttötavan muuttumisen myötä hyvin erilaisen ekspressiivisen luonteen (vrt. Kortelainen \& Albrecth 2019): "Täällä on paljon mehtämiehiä [...] syyskuu, nïn alkaa tämä mebtälinnun mebtuu, elokuussa jo on karbunmebtuu. [...] Sitten tulloo birviporukat." (H01)

Harrastuksena ja ajanviettotapana kalastus ja metsästys johtavat jälleen materiaalittomasti virkistykseen. Molemmissa kuitenkin tarvitaan erityisiä materialistisia lisävarusteita, jotka mahdollistavat kyseisen virkistystoiminnan (vrt. Sen 1993; Hirvilammi 2015). Käytännössä useimmat haastatteluissa mainitut virkistäytymisen muodot edellyttävät jonkin lisähyödykkeen käyttämistä kuten kanoottien, moottorikelkkojen, rekien, pyörien, telttojen, lumikenkien tai vähintäänkin retkeilyyn sopivien vaatteiden. Näiden materialististen lisäresurssien tulkitsen vaikkakin epäsuorasti, mutta kuitenkin välillisesti tukevan materiaalittoman luontosuhteen täyttymistä.

Kalastuksessa ja metsästyksessä materialistisia välttämättömyyksiä edustavat muun 
muassa pyyntivälineet. Virkistymiseen tähtäävänä toimintana nykymuotoinen kalastus tai metsästys ei näytä edellyttävän saaliin saamista välttämättömänä päämääränä. Mikäli toiminta kuitenkin johtaa pyydystämisen, eläin muuttuu väistämättä materialistiseksi hyödykkeeksi, vähintäänkin vatsantäytteeksi:

"Harrastuksia kalastus ja metätys. [...] Mehtämiebiä kun on ja on metässä ollu ikeäsä, siellä tietysti sitä [luontoa] arvostaa, osovaa arvostaa. [...] Jos sieltä hirviä ammuttaan, nïn kulluuban siitä aika ja hyvät libat saapi.” (H17)

Materialistisista piirteistään huolimatta metsästys ja kalastus esitetään toimintoina, joiden koetaan edistävän luonnossa kulkemista ja havaitsemista sekä sen myötä ennemmin tukevan kuin heikentävän monimuotoisia tapoja arvottaa luontoa.

\section{Luonto materialistisesti sellaisenaan ja muokattuna}

Luontoympäristön havaitseminen sellaisenaan virkistäytymisen mahdollistavana maisemallisena infrastruktuurina on riippuvainen maiseman ekspressiivisistä muodoista ja materialistisuus lopulta konkreettisesta toiminnasta. Siinä missä kuoppa on aikuisille vain monttu maisemassa, voi se lapsen mielikuvituksen ja leikin myötä muokkautua luontomateriaaleista syntyneeksi kodiksi: 'Leikkivät metsässä, meidän lähimetsässä. Siellä on semmonen monttu, nïn siellä oli heidän koti." (H14) Kaupunkien rakennettuihin ympäristöihin tottuneelle lapselle luontoympäristön ekspressiivisen muodon hahmottaminen leikkipaikkana ei näytä yhtä luontaiselta kuin luontoympäristössä kasvaneille, vaikkakin toiminta siihen suuntaan ohjautuukin:

"Yks päivä hän sanoi, että täälä ei ole ybtään kïpeilytelinettä. No ei ookkeaan, mut kysyin, missä sä kiïpeilet? Täällä on oikeastaan aika monta kiipeilytelinettä, kun tossa kolme punta, missä bän kiippeilee." (H10)

Materialistisen luontosuhteen kannalta esimerkki on mielenkiintoinen. Kaupunkien rakennetut kiipeilytelineet edustavat mitä selkeimmin teollisesti valmistettua materiaalista tuotetta. Tarina ei kerro, onko raaka-ainemateriaalina ollut kenties puu vai jokin muu, mutta hyödyke on materiaalinen sen kaikissa muodoissaan ja sitä tarvitaan leikkiin eli lopulliselta arvoltaan materiaalittomaan virkistäytymiseen. Luonnonpuiden materialistinen hyödyntäminen kiipeilytelineinä puolestaan hävittää teollisesti valmistetun tuotteen tarpeen. Materiaalisen kiipeilytelineen tarve ei siten häviä minnekään, mutta lisähyödykkeiden tarve kiipeilytelineen rakentamiseksi kylläkin.

Nämä leikkiin liittyvät toiminnot kuvastavat tapaa hyödyntää ja kuluttaa luontomateriaalia sellaisenaan. Astetta vahvemmin materialistiseksi käyttötavaksi voidaan määritellä luontomateriaalien muokkaaminen esimerkiksi kulkureittejä varten tarvittavaksi infrastruktuuriksi. Kevyimpänä muokkaustapana kertomuksissa näyttäytyvät lumeen tehtävät reitit, joiden tekemisessä voidaan hyödyntää myös pysyvästi muokattuja pohjia. Kuvaavaa kertomuksissa esitetyille reitistöille on, että ne on alun perin muokattu yhtä käyttötarkoitusta varten esimerkiksi hiihtoladuksi: "Ajanu sitä moottorikelkalla. Siellä joku käy bï̈tää ja me ollaan ajettu koirillakin. [...] Kakskyt kilsaa pitkë latu, menee tuolla keskellä korpee." (H16) tai moottorikelkkailun ajoradaksi: "Kun teemme pitkiä [koiravaljakko] safareita, käytämme myös virallisia moottorikelkekareittejä.” (H11), mutta reittejä hyödynnetään myös muihin tarkoituksiin.

\section{Materialismien kohtaamisia ja minimointia}

Alun perin teollista metsätaloutta varten tehdyt metsäautotiet erottautuvat näissäkin haastatteluissa merkityksellisinä virkistyskäytön reitistöinä: "byvät maastot treenata nimenomaan 
tuota hevosta, on mehtäantoteitä" (H03) tai kulkua helpottavina väylinä virkistyspaikoille (myös Kosenius ym. 2013). Metsäautotiet ovat ideaalinen esimerkki siitä, kuinka materialistisen metsäteollisuuden tarvetta varten luontoon muokattu tie muuntuu lopulliselta hyödyltään materiaalitonta virkistyskäyttöä tukevaksi. Riippumatta siitä, mitä lopputarkoitusta varten metsäautotiet tai virkistysreitistöt on rakennettu, ne edellyttävät luontomateriaalin muokkaamista. Yhteiskäyttöisyytensä myötä uusia virkistyskäytön reittejä ei tarvitse erikseen rakentaa, mikä osaltaan vähentää luonnon materialistista muokkaustarvetta. On kuitenkin huomioitava, että metsäautotiet eivät kaikilta osin ole virkistyskäyttöön vapaasti käytettävissä, vaan esimerkiksi metsäautoteitä paljon käyttävien matkailuyrittäjien on haettava tähän erillinen lupa kultakin maanomistajalta: "Meidän on kysyttävä heiltä kaikilta, voimmeko käyttää heidän maitaan.” (H11)

Erilaisista luvista ja lisensseistä huolimatta kukin omistaja viimekädessä päättää, mistä ja milloin metsää kaadetaan sekä mitä metsäautotietä silloin metsätalouden tarpeisiin käytetään. Nämä yllättävätkin arjen konfliktit ilmentävät tilanteita, joissa sommittuman samoihin elementteihin kohdistuvat, mutta toisistaan poikkeavat ekspressiiviset muodot (vrt. Kortelainen \& Albrecht 2019) törmäävät ristiriitaisesti. Metsäautotiet ja reitit materialistisina kulkureitteinä, metsänantimet materialistisina lopputuotteina ja metsämaisema materiaalisesti olemassa olevana muuttavat muotoaan. Virkistyskäytön näkökulmasta törmäys voi johtaa ongelmiin kuten vaikeakulkuisuuteen ja maiseman visuaaliseen viehättämättömyyteen (myös Milbourne $y m$. 2008). Karrikoidussa esimerkissä virkistyskäyttö tulee paperin jyräämäksi:

"Kaikki tulee kaadetuksi. [...] Tuolla menee pieni polku läpi metsän ja seuraavan kerran, kun menet sinne, metsä onkin poissa. Kun menet sienestämään tai marjastamaan, metsä onkin poissa. Joskus tekisi mieli näyttää se muille ihmisille "Hei katsokaa, teidän paperi kasvoi täällä.”. [...] Sunnnittelet jonkin kivan reitin ja se onkin poissa. Saattoivat talvella luvata, ettei tietä avata [metsätöitä varten], mutta ybtenä päivänä sitä käytetäänkin punnkuljetukseen. Samalla se tuboaa todella maalauksellisen kaunïn metsän ja metsän balki kulkevat polut." (H11)

Yhdestäkään kertomuksesta ei suoranaisesti välittynyt metsätalouden täyttä vastustamista vaan haitoista huolimatta pikemminkin pyrkimys ymmärtää sen olemassaoloa ja tarpeellisuutta. Kuten Valkonen (2008) on esittänyt, teollisesta metsätaloustoiminnasta johtuvat hakkuut kylläkin muuttavat muiden metsänkäyttäjien reittejä ja rajoittavat virkistystoimintoja tietyillä hakkuupaikoilla, tässäkään tapauksessa metsätalouden ei arvioitu poissulkevan metsän muita käyttötapoja kokonaan. Kertomusaineiston mukaan haitta voi olla yllättävä ja harmillinen, mutta yleisimmin ongelma on korjaantunut uusien reittivalintojen ja kohteiden kartoittamisen jälkeen:

"Meillä on lisenssit reitteibin, ja kun alkavat kaataa juuri näiden reittien yli, koko kauden sunnittelutyö alkaa alusta, koska he tulee ajamaan isoilla koneilla. Se ei ole kivaa, mutta se on heidän työtään. Aina on mabdollista etsiä vaibtoebtoinen tie tai reitti ja näin välttää kyseinen hakkunalue. [...] Näen Metsähallituksen tarpeellisunden, ja sen työn, mitä beidän täytyy tebdä. Olen melko varma, että he pyrkivät olemaan vabingoittamatta minun työtäni, mutta eivät aina voi välttää sitä, kun heillä on bakkuusuunnitelmat ja beidän täytyy toimittaa puuta eteenpä̈n.” (H21)

Kertomuksista välittyy pitkälti ymmärryshakuinen ja pienimpään haittaan pyrkivä tapa käyttää luontoa - niin ihmisten kesken kuin luonnon näkökulmasta. Luontoa kyllä hyödynnetään esimerkiksi materialistisiin tarkoituksiin rahan ansaitsemiseksi. Tällöin luontoa käytetään ja kulutetaan välineellisesti, mutta se pyritään toteuttamaan luonnon näkökulmasta kestävällä tavalla taloudellisesta maksimoinnista tinkien: 
"Se varmaan oikeesti ajattelee, että se ei halua, että se kasvaa. Vaan just sen verran mitä tää luonto kestää. [...] Että vaikeka se on yrittäjä, niin se ei ole semmonen bisnesyrittäjä. Vaan se tekee sen leivän, minkä se tarvitsee. [...] Se ei halua, että tämä olis Suomen suosituin turistikohde, koska sitten saattas ne kosket, ympäristö pilaantua.” (H10)

Varsinkin matkailuyrittäjät näyttävät tasapainoilevan luonnon materialistisen hyödyntämisen ja muiden arvojen välissä. Massaturismia edustavan Lapin kaltaiseksi alueen ei toivota kehittyvän vaan säilyttävän erämaisuutensa ja hiljaisuutensa vailla jatkuvaa liikennettä, bussilaumoittain turisteja tai matkailuyrityksiä jokaisen puun takana:

"Tämä erämaisuus ja hiljaisuus vailla liikenteen runsautta. Ei ole suuria moottorikelkekailuun tehtyjä väyliä. [...] Lapissa on koiravaljakkoyritys jokaisen kulman takana. [...] Lapilta kesti jonkin aikaa päästä sinne missä se nyt on ja minun mielestä sen kehitys olisi pitänyt pysähtyä vähän aiemmin. Mutta tämä [saisi pysyä] todella hiljaisena kulmauksena Suomessa, ei ruubkautunutta massaturismia, ei bussilaumoittain kuljetuksia." (H21)

Luontoympäristön ei ainakaan haluta muuttuvan pelkäksi taustamaisemaksi sinne rakennetuille keinotekoisille virkistyskeitaille. Kasvuhakuisen matkailukehityksen kannalta se ehkä voisi olla hyödyllistä, mutta se ei näytä edustavan pehmeitä luontomatkailun arvoja, joita alueella toivotaan edistettävän:

"Tällä puolen Pielistä toivoisin edistettävän ns. pehmeää matkailua. [...] Täällä kävi "viisas tyyppi" Helsingistä, joka kertoi, että me tarvitaan byvinvointikeskus keskelle Ruunaata. Siis, idiootti tulee sanomaan, että me tarvitaan joku wellness-keskus. Ei tänne sellaista tarvita. Joitakin retkeilyalueiden ja reittien risukeojen raivausta voi tebdä, vanhoista paikoista, mökeistä voi tehdä kivoja tai panostaa byvin merkeattuibin reitteibin. [...] Käyttää nïtä resursseja, mitä meillä on tekemättä enempää haittaa luonnolle - byödyntää vain sen verran kuin täytyy.” (H12)

Luonto halutaan kokea ja aistia fyysisesti sen läheisyydessä asumalla ja siellä kulkemalla. $\mathrm{Ne}$ puolestaan edellyttävät luontoon kuulumattomien materialististen rakenteiden kuten asuintalojen, mökkien, kotien ja laavujen lisäämistä sekä luonnon materialistista muokkaamista kuten reittien rakentamista ja risukoiden raivausta. Tämän seurauksena luontomaisema muuttuu ja materialistisia kytköksiä ei voi välttää. Pyrkimyksenä on kuitenkin ylenpalttisen materialistisen käytön hillintä käyttämällä ja muokkaamalla luontoa materialistisiin tarkoituksiin mahdollisimman säästeliäästi.

\section{Johtopäätökset}

Tavoitteenani on rikastuttaa käsitystä jälkiteollisiksi määrittyvien hyötyjen materialistisesta perustasta ja luonnon välineellisyydestä alueen asukkaiden näkökulmasta. Luontomaisema asuinympäristönä esitetään kaupunkiympäristöön verrattuna materialististen rakenteiden runsaudesta etäännyttävänä paikkana ja jälkiteollinen luontosuhde vastapainona materialististen hyödykkeiden täyttämälle elämälle. Vähiten materialistiset kytkennät liittyvät suojellun luonnon olemassaoloon sekä luontoympäristön herättämiin tunteisiin ja aistimuksiin, jotka eivät edellytä välitöntä fyysistä kosketusta luontomateriaan. Tyypillisimmin luonnon herättämät tuntemukset kytkeytyvät maaseudun ideaaleihin kuten maiseman esteettisen kauneuteen tai muutoin miellyttäviksi koettuihin ominaisuuksiin kuten hiljaisuuteen tai väljyyteen. Erämaisuus vaikuttaa luovan tähän aistikenttään oman lisänsä, mikä luo viehättävää jännitettä turvallisuudentunteen ja jännittävän välille.

Aineistosta tehtyjen tulkintojen perusteella yksilölliset jälkiteolliset käyttötavat ovat kuitenkin monin tavoin myös erilaisiin materialismeihin kytköksissä. Lopullinen hyöty voi olla luonnosta saatu materiaaliton virkistäytymisen kokemus, mutta kyseisen 
kokemuksen saavuttamiseksi tarvitaan välillisesti materialistisia lisävarusteita, tai luontoa itsessään on muokattava materialistisin keinoin. Virkistystäytyminen voi limittyä myös osaksi materialistista luonnonantimien keräämistä tai välillisesti tukea materialistisesti rahan ansaintaa. Näitä monimuotoisia materiaalittomia ja materialistisia kytkentöjä voi käytännössä yhdistellä loputtomasti.

Aineiston perusteella jälkiteollisen luontosuhteen materialistisuus voidaan kuitenkin tyypitellä neljään kategoriaan (Taulukko 1). 'Loppuhyödyn määrittelemä hyödykeperustaisuus' viittaa perinteisimmin muodostuvaan resurssiperäiseen materialistiseen luontosuhteeseen, jossa materialistinen hyödyke edellyttää pitkäkestoisen luontomateriaalin kuten puun tai eläimen tai lyhytkestoisen materiaalin kuten marjojen kovaa tai keskikovaa viemistä pois luonnosta. 'Luonnon muokkaaminen välilliseksi infrastruktuuriksi' kuvastaa luonnonvarojen kovaa tai keskikovaa resurssinomaista muokkaamista, jonka avulla päästään materiaalittomana toimintana miellettyyn loppuhyötyyn. Pehmeimpänä kategoriana 'luonnon kuluttaminen välillisesti infrastruktuurina' kuvaa luontosuhdetta, jossa luontoa ei suoranaisesti muokata käyttötarkoitusta varten vaan kulutetaan esimerkiksi kävelymaisemana tai leikkipaikkana, minkä myötä luontomateriaali voi myös ajansaatossa muokkautua. 'Luontosuhteen epäsuoran välillisesti mahdollistava hyödykeperustaisuus' ei suoraan heijastele sitä, miten luonnonvaraa konkreettisesti käytetään vaan tilannetta, jossa materialistiset hyödykkeet, kuten kovat pysyvät asuintalot tai keskikovat irralliset kanootit ovat välttämättömiä luontosuhteen lopullisen hyötyarvon kannalta.

Mikäli jokin toiminnoista tapahtuu taloudellista päämäärää varten, taloudellinen hyöty lisätään toiseksi lopulliseksi hyötyarvoksi nykyisten lisäksi. Aineiston perusteella on syytä

Taulukko I. Jälkiteollisen luontosuhteen materialismin kategoriat.

Table I. Materialists categories of postindustrial forest human-nature relationship.

\begin{tabular}{|c|c|c|c|}
\hline $\begin{array}{l}\text { Materialismin } \\
\text { kategoria }\end{array}$ & $\begin{array}{l}\text { Ala- } \\
\text { kategoria }\end{array}$ & Välillinen hyötyarvo & Lopullinen hyötyarvo (esim.) \\
\hline \multirow{3}{*}{$\begin{array}{l}\text { Loppuhyödyn } \\
\text { määrittelemä } \\
\text { hyödyke- } \\
\text { perustaisuus }\end{array}$} & \multirow[t]{2}{*}{ Kova } & $\begin{array}{l}\text { Virkistäytyminen: puunkaato, } \\
\text { pilkkominen }\end{array}$ & $\begin{array}{l}\text { Raaka-aine: lämmityspuut, } \\
\text { puuvalmisteiset hyödykkeet }\end{array}$ \\
\hline & & $\begin{array}{l}\text { Virkistäytyminen: metsästys, } \\
\text { kalastus }\end{array}$ & $\begin{array}{l}\text { Luonnonantimet: } \\
\text { liha, kala }\end{array}$ \\
\hline & Keskikova & $\begin{array}{l}\text { Virkistäytyminen: marjastus, } \\
\text { sienestys }\end{array}$ & $\begin{array}{l}\text { Luonnonantimet: } \\
\text { marjat, sienet }\end{array}$ \\
\hline \multirow{2}{*}{$\begin{array}{l}\text { Luonnon } \\
\text { muokkaaminen } \\
\text { välilliseksi } \\
\text { infrastruktuuriksi }\end{array}$} & Kova & $\begin{array}{l}\text { Muokkaaminen: } \\
\text { metsäautoteiden ja muiden } \\
\text { teiden tekeminen }\end{array}$ & $\begin{array}{l}\text { Virkistäytyminen: } \\
\text { ratsastus, valjakkoajelut, } \\
\text { kulkuväylän käyttö }\end{array}$ \\
\hline & Keskikova & $\begin{array}{l}\text { Muokkaaminen: } \\
\text { kevyempien reitistöjen } \\
\text { tekeminen }\end{array}$ & $\begin{array}{l}\text { Virkistäytyminen: ratsastus, } \\
\text { valjakkoajelut, moottorikelkkailu, } \\
\text { retkeily, vaeltaminen, kulkeminen }\end{array}$ \\
\hline \multirow{2}{*}{$\begin{array}{l}\text { Luonnon } \\
\text { kuluttaminen } \\
\text { välillisesti } \\
\text { infrastruktuurina }\end{array}$} & \multirow[t]{2}{*}{ Pehmeä } & $\begin{array}{l}\text { Kuluttaminen: kävelemällä, } \\
\text { juoksemalla, pyöräilemällä }\end{array}$ & $\begin{array}{l}\text { Virkistäytyminen: vaeltaminen, } \\
\text { lenkkeily, kuljeskelu, marjastus }\end{array}$ \\
\hline & & $\begin{array}{l}\text { Kuluttaminen: hyppimällä, } \\
\text { kiipeilemällä, leikkimällä }\end{array}$ & $\begin{array}{l}\text { Virkistäytyminen: kiipeily, } \\
\text { eläytymisleikit }\end{array}$ \\
\hline \multirow{3}{*}{$\begin{array}{l}\text { Luontosuhteen } \\
\text { epäsuoran } \\
\text { välillisesti } \\
\text { mahdollistava } \\
\text { hyödyke- } \\
\text { perustaisuus }\end{array}$} & \multirow[t]{2}{*}{ Kova } & $\begin{array}{l}\text { Pysyvän hyödykkeen } \\
\text { lisääminen: asuintalo, mökki }\end{array}$ & $\begin{array}{l}\text { Mahdollistaa muut käyttötavat ja } \\
\text { arvottamisen muodot }\end{array}$ \\
\hline & & $\begin{array}{l}\text { Pysyvän hyödykkeen } \\
\text { lisääminen: laavu, kota }\end{array}$ & Virkistäytyminen: retkeily \\
\hline & Keskikova & $\begin{array}{l}\text { Liikkuvien hyödykkeiden } \\
\text { käyttö: moottorikelkka, reki, } \\
\text { kanootti, teltta, vapa, ase }\end{array}$ & $\begin{array}{l}\text { Virkistäytyminen: kelkkailu, } \\
\text { melonta, vaeltaminen, } \\
\text { kalastus, metsästys }\end{array}$ \\
\hline
\end{tabular}


huomioida, että materialistinen käyttö voi olla sekä tyypiltään että voimakkuudeltaan erilaista. Kategorisoinnin alaluokkien ja voimakkuuden yhdistelmää voidaan havainnoida luonnon materialistista käyttöä kuvaavan nelikenttäkuvion avulla, jossa x-akseli kuvaa materialismin alakategoriaa pehmeästä kovaan ja y-akseli voimakkuutta minimistä maksimiin. Esimerkkinä kuviossa on havainnollistettu virkistäytymiseen liittyvää rakentamista, maanmuokkausta ja käyttömäärää (kuva 2). On syytä huomioida, että kuvio on laadullisesta aineistosta tehty havainnekuva, jossa akselien leikkauspiste kuvaa keskikovaa ja keskivoimakasta luonnon materialistista käyttöä. Määrälliselle aineistolle muuttaessa akselien leikkauspiisteelle tulee määrittää erikseen kullekin mitta-asteikolle sopiva arvo, joka ei välttämättä ole arvoltaan 0 .

Tutkimustulokset näyttävät hälventävän teollisen ja jälkiteollisten käyttötarkoitusten vastakkainasettelua tuomalla esiin erityisesti jälkiteolliseksi määrittyvien luontoarvojen materialistisia kytköksiä. Maisemaa on materialistisesti muokattu vahvasti metsätalouden lähtökohdista maastoa peraten, tietynlaisia puita istuttaen, metsäautoteitä rakentaen ja edelleen puita kaataen. Metsätalous ei silti näytä estäneen muita maiseman toiminnallisia muotoja, jotka valtaosin kietoutuvat tavalla tai toisella virkistäytymiseen. Metsätalouden tarpeista lähtenyt materialistinen muokkaaminen kuten metsäautotiet ovat esimerkki virkistyskäytön välillisestä mahdollistajasta, puunhakkuut vastaavasti maisemaa tyypillisemmin rumentavasta ja virkistyskäytön reittejä rajoittavasta toiminnasta. Luonnonvarojen materialistista käyttöä koskevista konflikteista huolimatta tutkimusaineistosta välittyy konsensushakuinen ymmärrys metsämaiseman erilaisia

Y-akseli: käytön voimakkuus

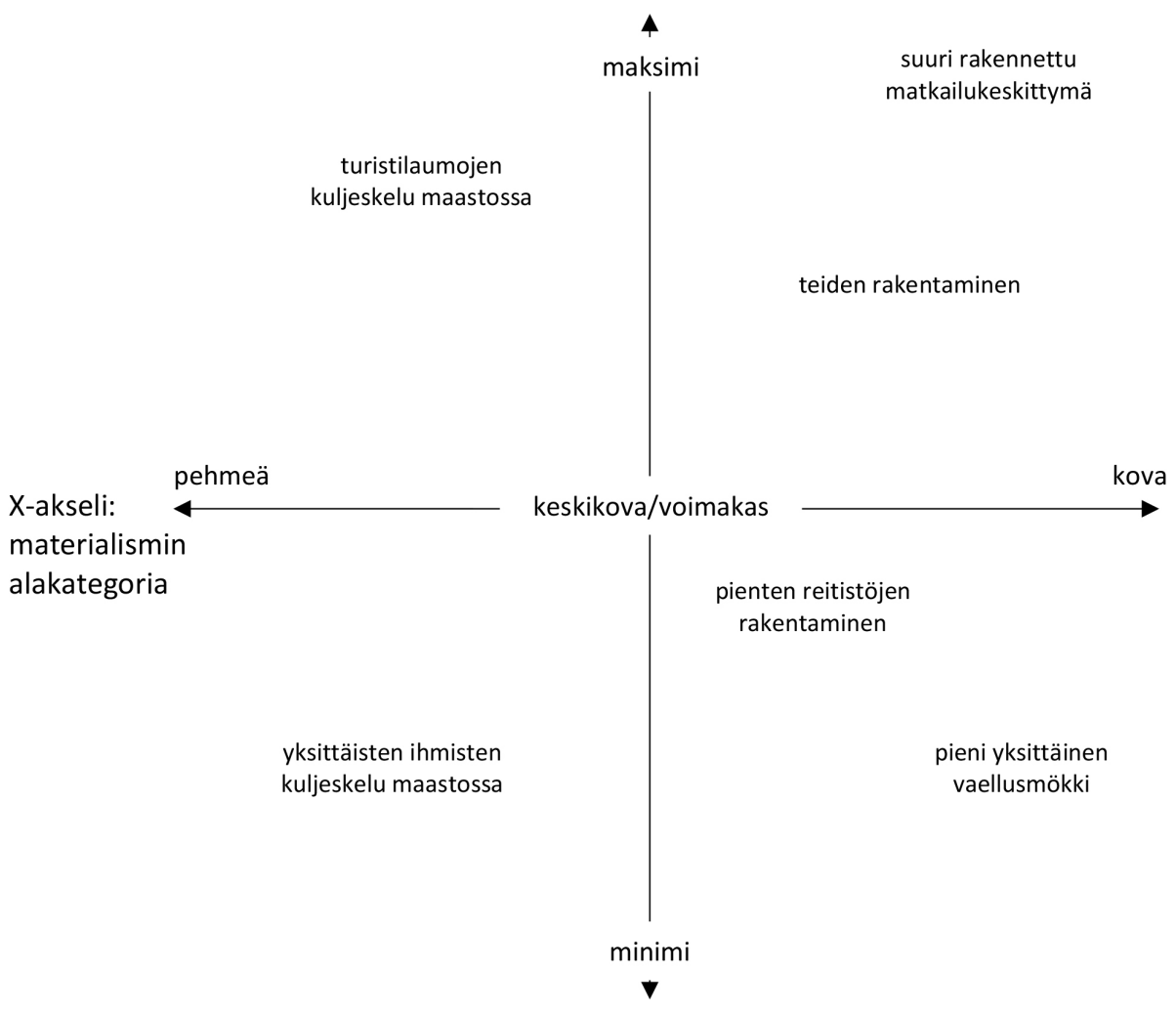

Kuva 2. Luonnon materialistisen käytön nelikenttä, esim. virkistäytyminen.

Figure 2. Materialistic utilisation of nature in the four-field chart, e.g. recreation. 
ekspressiivisiä muotoja kohtaan. Konsensus kuitenkin näyttää edellyttävän, että luontoa tuhotaan ja muokataan kuhunkin tarkoitukseen vain siltä osin kuin on välttämätöntä ja alueen muut käyttäjät huomioivalla tavalla. Kohtuullisuus ja ymmärtäväisyys muita hyödyntämiskeinoja kohtaan välittyvät aineistosta läpileikkaavina keinoina elää sopusoinnussa lähiluonnon ja -ihmisten kanssa.

Keskustelu ja kiistely luonnonvaroista näyttää helposti jumiutuvan ideaalitasolle sen sijaan, että luontomateriaalien erilaisia hyödyntämismuotoja analysoitaisiin yksityiskohtaisemmin. Osana tätä problematiikkaa näen sen, ettei luontomateriaalia muokkaavia sosiokulttuurisia käyttötapoja ole johdonmukaisen eksplisiittisesti tyypitelty ja nykyinen virkistäytymispainotteinen luontosuhde on yhdistynyt painokkaasti käsitykseen materiaalittomasta elämäntavasta. Artikkeli on ensinnäkin kriittinen muistutus siitä, että jälkiteollisenkin luontosuhteen seurauksena ihminen muokkaa ja muuttaa luontomateriaa monin eri tavoin. Artikkeli tarjoaa lisäksi konkreettisia välineitä, joiden avulla luontomateriaalien käyttömuotoja ja voimakkuutta voidaan eritellä - keinoja tehdä näkyväksi, miten ja kuinka voimakkaasti luonnonvaroja kulloinkin kulutetaan.

\section{Kiitokset}

Kiitän Keskitien säätiötä tutkimuksen rahoittamisesta. Lisäksi kiitän kahta nimetöntä arvioitsijaa ja päätoimittajaa selkeistä ja tarkoista kommenteista, jotka edesauttoivat artikkelin kriittisten kohtien täsmentämisessä.

\section{Lähteet}

Albrecht, E. \& Åkerman, M. (2016) Soidensuojelun osallistaminen ympäristöpolitiikan kokeiluna. Alue Ja Ympäristö 45(2) 4-19. https:/ / aluejaymparisto.journal.fi/article/view/ 60639

Almstedt, Å., Brouder, P. Karlsson, S. \& Lundmark, L. (2014) Beyond Post-Productivism: From Rural Policy Discourse to Rural Diversity. European Countryside 6(4) 297-306. https://doi.org/10.2478/euco-2014-0016 Atkinson, S., Fuller, S. \& Painter, J. (2012) Wellbeing and Place. Ashgate, Farnham \& Burlington.

Björn, I. (2000) Kaikki irti metsästä: Metsän kä̈tttö ja muntos taigan reunalla itäisimmässä Suomessa erätaloudesta vuoteen 2000. Väitöskirja, Joensuun yliopisto, Bibliotheca historica, 49. Suomen historiallinen seura, Helsinki.

Brandt, J. \& Vejre, H. (2004) Multifunctional landscapes - motives, concepts and perceptions. Teoksessa Brandt, J. \& Vejre, H. (toim.) Multifunctional Landscapes: Theory, Values and History, 3-31. WIT Press, Ashurst.

Clifford, N., Cope, M., Gillespie, T., French, S. \& Valentine, G. (2016) Getting started in geographical research: How this book can help. Teoksessa Clifford, N., Cope, M., Gillespie, T. \& French, S. (toim.) Key Methods in Geography, 3-18. Sage, Los Angeles \& London \& Dew Delhi \& Singapore \& Washington DC \& Melbourne.

Curtin, C. \& Kragh, G. (2014) Wildlife tourism: Reconnecting people with nature. Human Dimensions of Wildlife 19(6) 545-554. https://doi.org/10.1080/10871209.2014.921957

Eisto, I. (2009) Kylläpä kestää: Paikallisesti kestävän kehityksen ja ympäristölähtöisen kebittämistoiminnan subde harvaanasutulla maaseudulla. Väitöskirja, Joensuun yliopiston yhteiskuntatieteellisiä julkaisuja nro 1. https:// epublications.uef.fi/pub/urn_isbn_978-952-219-299-8/urn_isbn_978-952-219-299-8.pdf

Estola, E., Uitto, M. \& Syrjälä, L. (2017) Elämäkertahaastattelu. Teoksessa Hyvärinen, M., Nikander, P. \& Ruusuvuori, J. (toim.) Tutkimushaastattelun käsikirja, 153-173. Vastapaino, Tampere.

Eyvindson, K., Duflota, R., Triviño, M., Blattert, C., Potterf, M. \& Mönkkönen, M. (2021) High boreal forest multifunctionality requires continuous cover forestry as a dominant management. Land Use Policy 100 104918. https://doi.org/10.1016/j.landusepol.2020.104918.

Fletcher, R. (2009) Ecotourism discourse: challenging the stakeholders theory. Journal of Ecotourism 8(3) 269-285. https://doi.org/10.1080/14724040902767245

Gerring, J. (2007) Case Study Research: Principles and Practices. Cambridge University Press, Cambridge \& New York \& Melbourne \& Madrid \& Cape Town \& Singapore \& São Paolo.

Gulinck, H. (2004) Neo-rurality \& multifuntional landscapes. Teoksessa Brandt, J. \& Vejre, H. (toim.) Multifunctional Landscapes: Theory, Values and History, 63-74. WIT Press, Ashurst.

Haila, Y. (1990) Vibreään aikaan: Kirjoituksia ibmisen ekologiasta. Tutkijaliitto, Helsinki.

Haila, Y. (2003) 'Erämaa' ja ympäristöajattelun moniulotteisuus. Teoksessa Haila, Y. \& Lähde, V. (toim.) Luonnon politiikea, 174-204. Osuuskunta Vastapaino, Tampere.

Haila, Y. \& Lähde, V. (2003) Luonnon poliittisuus: Mikä on uutta? Teoksessa Haila, Y. \& Lähde, V. (toim.) 
Luonnon politiikeka, 7-36. Osuuskunta Vastapaino, Tampere.

Hallikainen, V. (2001) Suomalainen erämaakäsite ja erämaiden käyttö. Teoksessa Kangas, J. \& Kokko, A. (toim.) Metsän eri käyttömuotojen arvottaminen ja ybteensovittaminen, 111-119. Metsäntutkimuslaitoksen tiedonantoja 800/2001. Metla, Kannus.

Halonen, M. (2019) Booming, busting - turning, surviving? Socio-economic evolution and resilience of a forested resource periphery in Finland. Väitöskirja, Publications of the University of Eastern Finland, Dissertation in Social Sciences and Business Studies, 205.

Hiltunen, M. J., Pitkänen, K., Vepsäläinen, M., Rehunen, A. \& Shemeikka, P. (2014) Kylämökkeily-ympäristöt maaseutualueilla. Maaseudun unsi aike a 22(3) 68-80.

Hirvilammi, T. (2015) Kestävän byvinvoinnin jäljillä: Ekologisten kysymysten integroiminen byvinvointitutkimukseen. Väitöskirja, Sosiaali- ja terveysturvan tutkimuksia 136. Kela, Helsinki.

Hyvärinen, M. (2017) Kertomushaastattelu. Teoksessa Hyvärinen, M., Nikander, P. \& Ruusuvuori, J. (toim.) Tutkimushaastattelun käsikirja, 174-192. Vastapaino, Tampere.

Häikiö, L. \& Niemenmaa, V. (2007) Valinnan paikat. Teoksessa Laine, M., Bamberg, J. \& Jokinen, P. (toim.) Tapaustutkimuksen taito, 41-56. Gaudeamus Helsinki University Press, Helsinki.

Inglehart, R. \& Baker, W. E. (2000) Modernization, Cultural Change, and the Persistence of Traditional Values. American Sociological Review 65(1) 19-51. https://doi.org/10.2307/2657288

Jokiranta, A., Juntti, P., Ruohonen, A. \& Räinä, J. (2019) Aluksi. Teoksessa Jokiranta, A., Juntti, P., Ruohonen, A. \& Räinä, J. (toim.) Metsä meidän jälkeemme, 9-13. Like, Helsinki.

Kangas, J. \& Kokko, A. (2001) (toim.) Metsän eri käyttömuotojen arvottaminen ja ybteensovittaminen. Metsäntutkimuslaitoksen tiedonantoja 800/2001. Metla, Kannus.

Karjalainen, P. T. (1995) Elämä tässä talossa: Lähikartoitusta kirjallisuuden kautta. Alue Ja Ympäristö24(2) 15-24.

Kietäväinen, A. (2011) Asutustilallisten metsäsuhde ja metsän merkitys työpaikkana. Alue Ja Ympäristö 40(1) 42-52. https://aluejaymparisto.journal.fi/article/view/64497

Knuuttila, S. \& Rannikko, P. (2009) Syrjäinen maaseutu avoimina toivon tiloina. Teoksessa Nikula, J. (toim.) Maaseutuaiheita - Rural Motifs: Essays in Honour of Professour Leo Granberg, 49-52. Aleksanteri Institute, Series 5/2009.

Kort, W. A. (2011) "Lanscape" as a kind of place-relation. Teoksessa Malpas, J. (toim.) Place of Landscape: Concepts, Contexts, Studies, 27-43. MIT Press, Cambridge.

Kortelainen, J. \& Albrecth (2019) Tehdaskaupungin uusiutuminen: Äänekosken biotuotetehdas ja yhdyskunnan muutos. Terra 131(3) 137-151. https://terra.journal.fi/article/view/80315

Kosenius, A.-K., Juutinen, A., Neuvonen, M., Ovaskainen, V., Sievänen, T., Tolvanen, A. \& Tyrväinen, L. (2013) Virkistyskäjttöä edistävä metsänboito valtion talousmetsissä: byötyjen rabamääräinen arvo. Metlan työraportteja 261. Metsäntutkimuslaitos, Vantaa.

Kotilainen, J., Eisto, I., \& Vatanen, E. (2015) Uncovering mechanisms for resilience: Strategies to counter shrinkage in a peripheral city in Finland. European Planning Studies 23(1) 53-68. https://doi.org/10.1080 /09654313.2013.820086

Kramkowski, V. \& Mulvihill, P. (2017) Emerging dynamics of environmental governance in northern postproductivist regions. Local Environment 22(3) 350-364. https://doi.org/10.1080/13549839.2016.1205570

Krippendorff, K. (2004) Content Analysis: An Introduction to Its Methodology. $2^{\text {nd }}$ ed. Sage, Thousands Oaks \& London \& New Delhi.

Kuhmonen, T. \& Kuhmonen, I. (2015) Maaseutualueiden vaihtoehtoiset tulevaisuudet. Maaseudun uusi aika 23(2) 5-23.

Laurén, K. (2009) Metsä arkisen hyvinvoinnin lähteenä naisten kertomuksissa. Alue Ja Ympäristö 38(2) 13-24. https://aluejaymparisto.journal.fi/article/view/64386

Lähde, V. (2012) Luontokäsityksen tarkastelun ongelma. Teoksessa Lummaa, K., Rönkä, M. \& Vuorisalo, T. (toim.) Monitieteinen ympäristötutkimus, 97-109. Gaudeamus, Helsinki.

Malpas, J. (2011) Place and the problem of landscape. Teoksessa Malpas, J. (toim.) Place of Landscape: Concepts, Contexts, Studies, 3-26. MIT Press, Cambridge.

Manfredo, M., Teel, T. L. \& Zinn, H. (2009) Understanding global values toward Wildlife. Teoksessa Manfredo, M. J., Vaske, J. J., Brown, P. J., Decker, D. J. \& Duke, E. A. (toim.) Wildlife and Society - The Science of Human Dimensions, 31-43. IslandPress, Washington.

Mather, A. S. (1990) Global Forest Resources. Belhaven Press, London.

Mather, A. S. (2001) Forests of consumption: Postproductivism, postmaterialism, and the postindustrial forest. Environment and Planning C: Politics and Space 19(2) 249-268. https://doi.org/10.1068/c9914j

Mather, A. S., Hill, G. \& Nijnik, M. (2006) Post-productivism and rural land use: cul de sac or challenge for theorization? Journal of Rural Studies 22(4) 441-455. https://doi.org/10.1016/j.jrurstud.2006.01.004

McCarthy, J. (2005) Rural geography: multifunctional rural geographies - reactionary or radical? Progress in Human Geography 29(6) 773-782. https://doi.org/10.1191/0309132505ph584pr

Milbourne, P., Marsden, T. \& Kitchen, L. (2008) Scaling post-industrial forestry: The complex implementation 
of national forestry regimes in the Southern Valleys of Wales. Antipode 40(4) 612-631. https://doi. org/10.1111/j.1467-8330.2008.00626.x

MLL, Maanmittauslaitos (2011) Lieksan kylät, valtio, suojelu. Tietuetoimitus 21.11.2011. Lupa/maksu 18.1.2012.

MLL, Maanmittauslaitos \& Ek, K. (2016) Hallintorajat, teemakartoille, ei merialueita 10.2.2016. < https://etsin. fairdata.fi/dataset/bdce2f1b-6a66-4793-a652-9725dc491962>. 10.4.2020.

Nijnik, M., Nijnik, A., Lundin, L., Staszewski, T. \& Postolache, C. (2010) A study of stakeholders' perspectives on multifunctional forests in Europe. Forests, Trees and Livelihoods (19)4 341-358. https://doi.org/10.108 $0 / 14728028.2010 .9752677$

Oksanen, M. (2000) Johdanto. Teoksessa Haapala, A. \& Oksanen, M. (toim.) Arvot ja luonnon arvottaminen, 9-24. Gaudeamus, Helsinki.

O’Neill, J. (1993) Ecology, Policy and Politics: Human Well-Being and the Natural World. Routledge, London \& New York.

O’Neill, J., Holland, A. \& Light, A. (2008) Environmental values. Routledge Introductions to Environment Series. Routledge, London \& New York.

Pitkänen, K. (2011) Mökkimaisema muntoksessa: kulttuurimaantieteellinen näkökulma mökkeilyyn. Publications of the University of Eastern Finland. Dissertations in Social Sciences and Business Studies, no 31. https:// epublications.uef.fi/pub/urn_isbn_978-952-61-0605-2/urn_isbn_978-952-61-0605-2.pdf

Rannikko, P. (2008) Postproduktivismi metsässä. Teoksessa Karjalainen, T. P., Luoma, P. \& Reinikainen, K. (toim.) Ympäristösosiologian virrat ja verkostot, 83-95. Oulun yliopisto, Thule-instituutti, Oulu.

Rannikko, P. (2010) Luonnonkäytön muutos paikallisena legitiimihaasteena. Teoksessa Rannikko, P. \& Määttä, T. (toim.) Luonnonvarojen ballinnan legitimiteetti, 257-294. Vastapaino, Tampere.

Rannikko, P. \& Määttä, T. (2010) Johdanto: Luonnonvarakysymysten ajankohtaistuminen. Teoksessa Rannikko, P. \& Määttä, T. (toim.) Luonnonvarojen hallinnan legitimiteetti, 7-15. Vastapaino, Tampere.

Rannikko, R. \& Salmi, P. (2018) Towards neo-productivism? - Finnish paths in the use of forest and sea. Sociologia Ruralis 58(3) 625-643. https://doi.org/10.1111/soru.12195

Rannikko, P. \& Tervo, K. (2006) Hyvinvointiyhteiskuntaa rakentamassa - selviytymistarinoita ja tragedioita metsätöistä. Teoksessa Vehkamäki, S. (toim.) Metsät ja byvä elämä: Monitieteinen tutkimusraportti, 273-343. Metsäkustannus, Helsinki.

Rannikko, P., Varis, E., Piipponen, M., Karkinen, K., Klementjev, J., Kopoteva, I., Lehto, E., Polevštšikova, N. \& Otdelnov, P. (2015) Metsätyökylän muodonmuutos Venäjän Karjalassa. Idäntutkimus 22(2) 3-16. https://journal.fi/idantutkimus/article/view/78017/38933

Roiko-Jokela, H. (2003) Arvotja edut ristiriidassa - Kiistoja valtion metsistä: Hattuvaara, Kessi, Murbijärvi, TalaskangasSopenmäki, Porkkeasalo. Minerva Kustannus, Helsinki.

Sairinen, R., Tiainen, H. \& Mononen, T. (2017) Talvivaara mine and water pollution: An analysis of mining conflict in Finland. The Extractive Industries and Society 4(3) 640-651. https://doi.org/10.1016/j. exis.2017.05.001

Sayer, A. (1992) Method in Social Science: A Realist Approach. $2^{\text {nd }}$ ed. Routledge, London \& New York.

Schein, R. H. (2010) Cultural Landscapes. Teoksessa Gomez, B. \& Jones, J. P. III (toim.) Research Methods in Geography: A Critical Introduction, 222-240. Wiley-Blackwell, Malden.

Sen, A. (1993) Capability and well-being. Teoksessa Nussbaum, M. \& Amartya, S., (toim.) The Quality of Life, 30-53. Clarendon Press, Oxford.

Sepänmaa, Y. (2006) Millainen metsä on kaunis? Teoksessa Jalonen, R., Hanski, I., Kuuluvainen, T., Nikinmaa, E., Pelkonen, P., Puttonen, P., Raitio, K. \& Tahvonen, O. (toim.) Uusi metsäkirja, 241-246. Gaudeamus, Helsinki.

Soini, K., Pouta, E., Uusitalo, M. \& Kivinen, T. (2008) Maiseman arvottaminen monitieteisenä tutkimushaasteena. Teoksessa Soini, K., Pouta, E., Kivinen, T. \& Uusitalo, M. (toim.) Maaseutumaiseman muntos, arvottaminen ja eurooppalainen maisemayleissopimus, 9-19 Maa- ja elintarviketalous 135. MTT taloustutkimus, Helsinki.

Stake, R. E. (1995) The art of case study research. Sage: Thousand Oaks, California.

Swedberg, R. (2012) Theorizing in sociology and social science: turning to the context of discovery. Theory and Society 41(1) 1-40. https://doi.org/10.1007/s11186-011-9161-5

SYKE, Suomen ympäristökeskus (2008) Corine maanpeite 2006 1.3.2008. < http:/ / metatieto.ymparisto.fi:8080/ geoportal $/ \mathrm{catalog} / \mathrm{search} / \mathrm{resource} /$ details.page?uuid $=\{4438$ F7E1-2927-4854-B8F8-0EE8E8822C53 $\}>$. 3.5.2020.

Tanskanen, M. (2000) Näkyvän takana: Tutkimus metsäojitetun suomaiseman kulttuurisuudesta. Väitöskirja, Joensuun yliopisto, Maantieteen laitos, Julkaisuja No 8.

Uusitalo, E. (2020) Etnografian reittejä kylien ajallisunteen ja aineellisuuteen. Väitöskirja, Helsingin yliopisto, Ruraliainstituutti, Julkaisuja 37.

Vaara, M. \& Saastamoinen, O. (2006) Metsät ja puut arjen ajankäytössä - Kuvakulmia suomalaiseen elämäntapaan. Teoksessa Vehkamäki, S. (toim.) Metsät ja byvä elämä: Monitieteinen tutkimusraportti, 345-403. Metsäkustannus, Helsinki. 
Valkonen, J. (2008) Eletyistä luonnoista funktionaalisiin ympäristöihin. Teoksessa Karjalainen, T. P., Luoma, P. \& Reinikainen, K. (toim.) Ympäristösosiologian virrat ja verkostot, 245-264. Oulun yliopisto, Thule-instituutti, Oulu. Venkatesan, S., Bear, L., Harvey, P., Lazar, S., Rival, L. \& Simone, AM (2018) Attention to infrastructure offers a welcome reconfiguration of anthropological approaches to the political. Critique of Anthropology 38(1) 3-52. https://doi.org/10.1177/0308275X16683023

VRK, Väestörekisterikeskus (2011) Lieksa RHR-rakennusaineisto. Tietolupapäätös Dnro 1929/410/11.

Wilson, G. A. (2001) From productivism to post-productivism ... and back again? Exploring the (un)changed natural and mental landscapes of European agriculture. Transactions of the Institute of British Geographers 26(1) 77-102. https://doi.org/10.1111/1475-5661.00007

Woods, M. (2016) Territorialisation and the assemblage of rural place: Examples from Canada and New Zealand. Teoksessa Dessein, J., Battaglini, E. \& Horlings, L. (toim.) Cultural Sustainability and Regional Development: Theories and Practices of Territorialisation, 29-42. Routledge, London \& New York. [eBook 2016]

Yin, R. K. (2003) Case Study Research: Design and Methods. $3^{\text {rd }}$ ed. Applied Social Research Methods Series vol. 5. Sage, Thousand Oaks. 